\title{
A RELAÇÃO ENTRE O TRABALHO DOS CATADORES DE MATERIAIS RECICLÁVEIS DA REDE DE RECICLAGEM DO ESTADO DO RIO DE JANEIRO E A MANUTENÇÃO DA INDÚSTRIA DE RECICLAGEM ${ }^{1}$
}

The relationship between the work of informal recyclable material collectors in the Rio de Janeiro state recycling network and recycling industry maintenance

La relación entre el trabajo de recicladores de materiales de reciclaje de la red de reciclaje del estado de Rio de Janeiro y el mantenimiento de la industria del reciclaje

Uilmer Rodrigues Xavier da Cruz

Doutorando em Geografia pela Universidade Federal de Minas Gerais uilmer@ufmg.br

Artigo enviado para publicação em 02/10/2019 e aceito em 11/05/2020

DOI: $10.12957 /$ tamoios.2020.43890

\section{Resumo}

O espaço capitalista é constituído a partir das relações sociais que, traduzidas segundo uma lógica de produção, circulação e acúmulo de capital, do consumo e da exploração de força de trabalho, instituem-se em relações de trabalho que centralizam ou marginalizam os sujeitos, fragmentando a sociedade em classes. Esta reflexão corresponde a um olhar específico acerca de uma das categorias de trabalho que compõe a lógica capitalista: a catação de materiais recicláveis, como os sujeitos que compõem esta prática: os catadores. Para tanto, o objetivo deste trabalho é o de compreender qual a relação entre o trabalho de catação realizado pelos catadores de material reciclável da rede de reciclagem do Rio de Janeiro e a manutenção da indústria de reciclagem do Estado. Neste sentido, buscamos destacar os conceitos de espaço e rede e a correspondência destes conceitos com este fenômeno, em que os trabalhadores envolvidos são pilares fundamentais, com seus papéis e práticas laborais. Embora não se possa afirmar que a presente proposta concentra-se em uma 'única' verdade a respeito deste fenômeno, busca-se colaborar, enquanto uma das possíveis análises a respeito do trabalho de catação intrínseco à Indústria de Reciclagem e, por sua vez, à lógica capitalista, a partir de uma abordagem Geográfica.

Palavras-chave: Espaço; Rede; Catadores de Materiais Recicláveis; Indústria da Reciclagem.

\begin{abstract}
The capitalist space is formed from social relations that, when translated according to a logic concerning capital production, circulation and accumulation, as well as work force consumption and exploitation, are established as labor relations that either centralize or marginalize the subjects, fragmenting class society. This reflection corresponds to a specific view regarding one of the work categories that make up capitalist logic, namely recyclable material collection, through the subjects that make up this practice, i.e. the collectors. To this end, the aim of the present study is to understand the relationship between the collection work carried out by recyclable material collectors from the Rio de Janeiro recycling network and the maintenance of the state's recycling industry. In this context, we seek to highlight space and network concepts and associate these concepts with this phenomenon, where worker roles and work practices comprise crucial pillars. Although the present proposal does not focus on a 'single' truth regarding this phenomenon, it attempts to collaborate as one of the possible analyses regarding collecting activities intrinsic to the Recycling Industry and, in turn, capitalist logic, from a Geographic approach.
\end{abstract}

Keywords: Space; Network; Recyclable Material Collectors; Recycling Industry. 


\section{Resumen}

El espacio capitalista está constituido por las relaciones sociales que, traducidas según una lógica de producción, circulación y acumulación de capital, consumo y explotación de la fuerza laboral, se establecen en relaciones laborales que centralizan o marginan a los sujetos, fragmentando sociedad de clases. Esta reflexión corresponde a una mirada específica a una de las categorías de trabajo que conforman la lógica capitalista; la colección de materiales reciclables, como los temas que componen esta práctica: los coleccionistas. Por lo tanto, el objetivo de este trabajo es comprender cuál es la relación entre el trabajo de recolección realizado por recolectores de materiales reciclables de la red de reciclaje en Río de Janeiro y el mantenimiento de la industria de reciclaje del estado. En este sentido, buscamos resaltar los conceptos de espacio y red y la correspondencia de estos conceptos con este fenómeno, en el cual los trabajadores involucrados son pilares fundamentales con sus roles y prácticas laborales. Aunque no se puede decir que la presente propuesta se centra en una verdad "única" con respecto a este fenómeno, busca colaborar como uno de los posibles análisis con respecto al trabajo de recolección intrínseca a la industria del reciclaje y, a su vez, a la lógica capitalista, desde un enfoque geográfico.

Palabras-clave: Espacio; Red; Recolectadores de Materiales Reciclables; Indústria del Reciclaje.

\section{Introdução}

A atual reflexão tem como objetivo compreender qual a relação entre o trabalho de catação realizado pelos catadores de material reciclável da rede ${ }^{2}$ de reciclagem do Estado do Rio de Janeiro (RRERJ) e a manutenção da indústria de reciclagem. Este fiocondutor pode ser justificado a partir da noção de que os trabalhadores envolvidos com a prática de catação de materiais recicláveis correspondem a uma rotina de trabalho que é perpassada pelo circuito inferior da economia, cujas práticas são mantidas por sujeitos que, em outras palavras, são 'marginalizados' no sistema capitalista de produção, necessitando buscar modos de transpor limitações (simbólicas e materiais) para sobrevivência. Por outro lado, a existência destes trabalhadores também está relacionada à manutenção do circuito superior da economia ${ }^{3}$, referente à indústria da reciclagem, que é caracterizado pelo beneficiamento direto de determinada classe social através do acúmulo (permanente) de capital.

O espaço é resultante das relações sociais e, por sua vez, estas se mantêm somente a partir da existência de um recorte espacial, conforme nos traz Corrêa (2000). A partir dessa compreensão, é possível afirmar que o espaço constituído sob o recorte do sistema capitalista tem características específicas atreladas ao funcionamento deste sistema e, por sua vez, as relações sociais também corresponderão a esta lógica.

Harvey (2011) afirma que o capital(ismo) não é um objeto fixo, imutável, porém um processo. As relações sociais e, por sua vez, de classe, estão dispostas em consonância com uma lógica: a da acumulação permanente de capital de uma classe em detrimento de outra(s). Para tanto, o autor destaca que a sociedade se organiza em setores/segmentos, cujas ações e práticas, através das relações, são perpassadas pelas necessidades desse sistema. Quando, no parágrafo anterior, afirmamos que o espaço geográfico é constituído por singularidades intrínsecas ao capital, referimo-nos aos processos contínuos da produção de mercadorias e à geração de lucro, a partir do valor excedente cobrado por tais produtos e, para além, ao trabalho não pago executado pela classe menos abastada (os trabalhadores) que, sob uma perspectiva marxista, recebe a alcunha de 'mais-valia'.

É válido destacar que, segundo o autor supracitado, a característica de dinamicidade do sistema capitalista de produção configura a alteração constante em 
seus modos de manutenção (formas de exploração de força de trabalho, barateamento de custos de matéria-prima em relação ao valor do produto, crédito de capital financeiro etc.). Isso significa que, ao longo da história da humanidade, que se encontra com a história do capitalismo e por ser esta, apesar de não linear, marcada por grandes mudanças, a partir do século XVIII, a partir daí, então, as relações se alterarão de modo a corresponder às necessidades dinâmicas do Capital.

Assim como Harvey (2011) afirma que as crises relacionadas à escassez de matéria-prima e também ao aumento significativo do exército industrial de reserva (que resulta na impossibilidade do escoamento de produção justificada pela redução de poder aquisitivo da população), constituem-se enquanto cenários não planejados, porém necessários para a restauração da 'saúde' do sistema capitalista, o autor também discute que, a partir das crises, surgem alternativas para a retroalimentação do sistema, como outras formas originais de matéria-prima e outros postos de trabalho - criados pela necessidade de sobrevivência da população pobre e trabalhadora.

Em consonância com o exposto e o objetivo do trabalho elencado no primeiro parágrafo deste texto, o grupo de sujeitos que se relaciona a esta reflexão enquanto 'pesquisados', porém ativos no processo de pesquisa, a partir de seus olhares sobre o real (suas realidades de trabalho), constitui-se de catadores de material reciclável, especificamente do Estado do Rio de Janeiro. Como já definido, estes trabalhadores constituem suas relações de trabalho a partir do circuito inferior da economia - Santos (2008) - e, concomitantemente, suas vivências serão perpassadas por essa condição.

Ainda, para que fosse possível o destaque para uma análise acerca dos papéis desses trabalhadores como a atual, foram aplicados 3084 questionários em toda a RRERJ $^{4}$, sendo, desta população total, 1305 mulheres e 1779 homens, em sua maioria com baixo grau de escolaridade (Ensino Fundamental 1 e 2 que, em geral, são incompletos), cerca de $71 \%$ de negros ${ }^{5}$, além de outros dados que serão melhor apresentados na segunda seção do desenvolvimento deste artigo.

Longe de afirmar que os dados apresentados acima são uma análise das complexas vivências dos catadores de papel, bem como de suas relações com a indústria de reciclagem, pode-se dizer que tais dados devem ser encarados como um 'ponto de partida' para se pensar quem são esses trabalhadores e como suas identidades ${ }^{6}$ se relacionam aos espaços que compõem.

Os dados elencados a partir dos questionários aplicados com a população em questão e a compreensão de que suas vivências são perpassadas por suas facetas identitárias que, de modo intersubjetivo, estão diretamente atreladas ao funcionamento do capitalismo e, por sua vez, ao acúmulo de capital permanente sob posse dos sujeitos que compõem o circuito superior da economia capitalista, colaboram para a noção primária de que o espaço a que nos referimos aqui, a partir de Corrêa (2000), enquanto resultante e matriz para a manutenção das relações sociais, é conjuntural às características deste sistema.

A presente reflexão busca produzir um debate que colabore com os campos específicos da Geografia, sobretudo ao escopo acadêmico-científico brasileiro, não enquanto um ponto de chegada acerca da temática, porém enquanto uma das possibilidades a serem observadas acerca dos fenômenos que se relacionam ao sistema capitalista, ao espaço e à economia tangente a este, que, em suma, é baseada em uma sociedade de classes e na concentração desigual de capital de maneira abissal. 


\section{Material e métodos}

A metodologia proposta neste artigo é a mista participante, que é uma junção de métodos qualitativos e quantitativos, além de refletir o entendimento do pesquisador, uma vez que, para esse tipo de metodologia, é necessário que o pesquisador esteja inserido no contexto do objeto analisado como participante, para que as reflexões sejam o reflexo mais aproximado possível de suas próprias vivências e observações.

A fim de apresentar o catador e suas condições de vida, recorremos a Santos (1995), que nos diz que se a desigualdade é um fenômeno socioeconômico, a exclusão é, principalmente, um fenômeno cultural e social, um fenômeno de civilização. E, assim, a cultura se fortalece e se legitima por um discurso histórico supostamente verídico e que tem por objetivo não só ditar o que precisa ser seguido, mas também rejeitar tudo aquilo que não se enquadra. Refere-se a um processo histórico pelo qual uma cultura, através de um discurso de verdade, gera o interdito e o rejeita. Aos catadores, então, são empurrados para a condição de marginalidade na sociedade e o seu lugar é visto como subalterno e invisível, ainda que ocupe uma função de suma importância na rede de produção da reciclagem. Buscamos, então, levantar as condições socioeconômicas dos catadores, em que prevalece seu caráter de exclusão e invisibilidade social.

Assim, é preciso partir do fenômeno em si e não da sua representação, indo além das aparências e superando as primeiras impressões ofertadas pelas redes de produção e pelas políticas públicas estabelecidas para o cenário histórico e geográfico analisado, na tentativa da reconstrução da realidade no plano abstrato e no retorno ao plano concreto.

O trabalho de pesquisa, propriamente dito, a observação no campo, corresponde à grande escala e, neste nível, é somente uma parte dos fenômenos que pode ser convenientemente apreendido; os outros devem ser antevistos em escala menor e é preciso, para isto, utilizar representações que a pesquisa no terreno não pode fornecer. $O$ trabalho de campo, para não ser somente um empirismo, deve articular-se à formação teórica que é, ela também, indispensável. Saber pensar o espaço não é colocar somente os problemas no quadro local; é também articulá-los eficazmente aos fenômenos que se desenvolvem sobre extensões muito mais amplas. Não é menos verdade que a pesquisa, na medida em que ela corresponde à extração de um abstrato a partir de um concreto, pela pesquisa e pela observação de campo, dá uma grande importância ao nível de conceptualização em grande escala (evidentemente, a pesquisa pode também partir, sobretudo, das abstrações já elaboradas; a formação dos pesquisadores é então diferente e muito menos titubeante). (LACOSTE, 2006, p. 91).

Dentre os documentos que foram analisados, destacamos o relatório desenvolvido pela Secretaria Estadual do Meio Ambiente - CRS/ Fundação Getúlio Vargas - FGV e pela ONG PANGEA - Centro de Estudos Socioambientais, que identificou e cadastrou, em 2014, 3.084 (três mil e oitenta e quatro) catadores e catadoras de materiais recicláveis e realizou diagnóstico socioeconômico de empreendimentos econômicos solidários da rede produtiva de catadores em 41 municípios do estado do Rio de Janeiro ${ }^{7}$. Deste levantamento, foi realizado um relatório em 2015 para prestação de contas, tendo sido entregue no Sistema de Gestão de Convênios e Contratos de Repasse do Governo Federal - SICONV.

Concomitantemente, foi pertinente promover levantamento de dados secundários do setor da reciclagem, bem como IBGE, IPEA, leis, artigos, teses, relatórios, dissertações, em que se pretende traçar um panorama geral do funcionamento 
da reciclagem no Estado: os tipos de materiais coletados (ou seja, as redes do papel, do plástico, do alumínio, do $\mathrm{OGR}^{8}$, papelão). Para Silva \& Mendes, "a pesquisa documental representa recurso capaz de trazer contribuições importantes para a pesquisa, porque pode auxiliar na compreensão dos fatos. Assim, os documentos merecem atenção especial nos estudos qualitativos" (2013, p. 210).

O caminho que tomaremos a seguir, na seção 'discussões', divide-se em duas subseções e, posteriormente, serão seguidas das considerações finais. Discorrer-se-á, na primeira seção, a respeito de uma discussão acerca do conceito de espaço e de rede e a relação destes conceitos conjunturalmente com o capitalismo e com o trabalho (o que inclui também a classe trabalhadora) enquanto necessidade e barreira- Harvey (2011)para a manutenção deste sistema, através dos circuitos da economia- Santos (2008). A segunda seção tratará, especificamente, de uma abordagem acerca do trabalho de catação de materiais recicláveis, os trabalhadores que compõem essa realidade e, neste caso, a RRERJ, na relação destes com a indústria da reciclagem.

\section{Discussões}

\section{Espaço, rede e relações de trabalho no sistema capitalista}

$\mathrm{Na}$ introdução deste artigo, destacamos logo um 'pontapé' para se compreender o conceito de espaço sob a perspectiva da ciência geográfica, a partir de Corrêa (2000). $\mathrm{O}$ autor leva em conta a subjetividade dos indivíduos que constituem suas relações espacialmente, sendo que o espaço depende da inteligibilidade destes sujeitos e, de maneira concomitante, tais relações somente ocorrem a partir de uma escala espacial.

A definição apresentada pelo autor, embora não possa ser lida de maneira simplista, permite-nos analisar o espaço enquanto uma esfera material, porém também simbólica, no tocante aos sujeitos que o constituem. Neste sentido, Souza (2013) afirma que o espaço é composto pelo substrato material, delimitado e físico, bem como pelas diversas relações que neste substrato ocorrem de maneira simbólica e configuram, a partir deste, um recorte 'sócio-espacial'. O autor ainda nos traz uma breve discussão a respeito de 'produção espacial' que, em suas palavras:

(...) a produção do espaço pode se referir tanto à sua (re)produção, nos marcos do modelo social hegemônico, capitalista e heterônomo, quanto à emergência de novas significações, novas formas e novas práticas (que, em alguns casos, desafiarão explicitamente o status quo hegemônico)" (SOUZA, 2013, p. 42).

$\mathrm{Na}$ medida em que produzimos o diálogo entre os dois autores supracitados, também podemos apresentar outra compreensão acerca do conceito do 'espaço', que parte de Massey (2008). Segundo a autora, o espaço é resultado das interrelações compostas por diferentes sujeitos e, por conta destas, é múltiplo e, para além, está em constante construção, assumindo uma característica de dinamicidade. Essas condições colocam então o espaço não enquanto um resultante 'fechado', em uma história fixa, porém em um constante devir, um processo nunca findável, o que Massey (2008) denomina 'estórias-abertas-até-agora'. Segundo a autora:

Conceber o espaço como um recorte estático através do tempo, como representação, como um sistema fechado, e assim por diante, são todos modos de subjugá-lo. Eles nos permitem ignorar sua verdadeira relevância: as multiplicidades coletâneas de outras trajetórias e a necessária mentalidade aberta de uma subjetividade espacializada. (MASSEY, 2008, p. 94) 
Ao voltarmos para a proposta destacada para este artigo, visando compreender a relação entre o trabalho de catação (e os sujeitos envolvidos com este trabalho) com a manutenção da indústria de reciclagem, localizamos a necessidade de 'espacializar' este questionamento. No ponto em que os autores e a autora supracitados concordam, o espaço é concomitante à existência de relações sociais (seja enquanto componente, resultante ou enquanto o próprio espaço).

No caso específico desta reflexão, o espaço a que nos referimos se refere ao constituído a partir da lógica de produção capitalista e as características que a compõe. No entanto, é mister considerarmos que as configurações atuais do sistema capitalista têm especificidades relacionadas à temporalidade em que são constituídas e, ao contrário do capitalismo moderno industrial (muito discutido por Marx, por exemplo), são marcadamente entalhadas pela fluidez das relações sociais, a escassez de matériaprima e o acúmulo de capital financeiro Harvey $(2011)^{9}$.

Harvey (2011) argumenta que a atual configuração do capital constitui-se em uma era de expansão global, de inter-relações entre Estados-Nação e, além disso, uma 'transnacionalização' do capital - empresas e corporações financeiras - que, após a década de 1970, assumem uma considerável centralidade em relação aos EstadosNação: por exemplo, polos fabris em países em desenvolvimento (ou de capitalismo tardio/periférico) para suprir as necessidades da geração de lucro em países de capitalismo central.

Deste modo, é possível afirmarmos que os espaços que se constituem a partir de determinadas escalas muito se aproximam da perspectiva de Massey (2008), enquanto 'abertos' e 'múltiplos' e, para além do que podemos destacar enquanto uma característica desse espaço, estabelece-se enquanto multiescalar, em que diversas escalas se superpõem e o compõem. Assim, as características de trabalho e de acúmulo de capital permanente a partir da produção de lucro serão perpassadas de maneira multiescalar por uma lógica 'global' em relação à 'local' (e vice-versa).

Neste caminho, os catadores de material reciclável que correspondem a este recorte de análise terão suas inter-relações espacializadas, incluindo as relações de trabalho, com base em uma lógica que não só corresponde às suas necessidades de sobrevivência (sobretudo financeiras), como também à lógica de beneficiamento da indústria de reciclagem - que, em outras escalas, relaciona-se a outras indústrias, enquanto fornecedoras de matéria-prima de baixo custo para fabricação de novas mercadorias.

Essa condição coloca esses sujeitos em posições relacionadas aos seus postos de trabalho e, por sua vez, o modo com o qual irão vivenciar seus cotidianos é perpassado pela condição de catadores ${ }^{10}$. Harvey (2008) colabora para a compreensão desses 'novos' postos de trabalho a partir da parte II de sua obra "Condição pósmoderna: uma pesquisa sobre as origens da mudança cultural', a qual trata das mudanças político-econômicas no capitalismo do final do século XX.

$\mathrm{O}$ autor argumenta que, anteriormente, o modo de produção fundamentado no modelo fordista, que produzia em massa e, destarte, contava com o consumo de mercadorias em massa, dependia de uma regulação do Estado e de sua manutenção. Com a saturação desta configuração, para que se mantenha o regime de acumulação de capital, o modo de produção se altera e surgem novas configurações de trabalho, com outro regime de horas, em que o mais-valia é obtido pela intensidade e não pela quantidade de horas de produção.

Dentro desses novos moldes, em que se altera a organização do Capitalismo, também se reconfigura o Estado, de modo a descentralizar o capital (um capital sem fronteiras, segundo Harvey (2008), a ponto de se poder afirmar que a 'desorganização' 
do trabalho é quase uma consequência, muito mais do que uma causa nesta reestruturação. Este é o ponto que destaca o modo com o qual estes trabalhadores constituem suas relações de trabalho, que se delimita a partir de uma rede (RRERJ), composta não apenas por estes, como também por outros sujeitos que se estabelecem enquanto atores na lógica de produção capitalista.

Diante disso, não se pode deixar de mencionar dois conceitos fundamentais, tratados por Ricardo Antunes (2009), que ajudam a elucidar os sentidos do trabalho, especialmente nas relações de trabalho contemporâneas: "a classe-que-vive-dotrabalho" e "as metamorfoses do trabalho". Ambos conceitos se preocupam em fazer compreender o funcionamento das formas de trabalho atuais e englobam as mudanças ocorridas após os grandes movimentos oriundos do capitalismo que estimulam a reflexão na origem do proletariado, que é a mão-de-obra principal desse sistema econômico e social.

Abordar a "classe-que-vive-do-trabalho" é o mesmo que reproduzir o conceito de Marx para "classe trabalhadora". Contudo, a primeira expressão representa mais a contemporaneidade dessa classe, buscando enfatizar o ser social com todas as suas especificidades atuais (Antunes, 2009). Nesse sentido, os trabalhadores das redes de reciclagem, sujeitos tratados neste artigo, fazem parte dessa "classe-que-vive-dotrabalho", por representarem uma categoria derivada das mutações ou metamorfoses que ocorreram nas novas relações de trabalho.

Pode-se dizer, de certo modo, que a "classe-que-vive-do-trabalho" inclui todos os tipos de trabalhadores, seja aquele considerado produtivo, que está envolvido diretamente na produção que gera lucro ou mais valia e está no centro dessa classe; seja o considerado trabalhador improdutivo, que se envolve nos outros processos de uma rede de produção:

(...) aqueles cujas formas de trabalho são utilizadas como serviço, seja para uso público ou para o capitalista, e que não se constituem como elemento diretamente produtivo, como elemento vivo do processo de valorização do capital e de criação de mais-valia. São aqueles em que, segundo Marx, o trabalho é consumido como valor de uso e não como trabalho que cria valor de troca. (ANTUNES, 2009, p. 102)

Fazendo uma analogia, seria como dizer que um operário de uma fábrica é um trabalhador produtivo e o gerente é um trabalhador improdutivo, uma vez que não tem contato direto com a produção. $\mathrm{O}$ trabalhador improdutivo pertence a uma categoria em expansão no capitalismo contemporâneo, que é fundamental para se compreender as relações de trabalho atuais. Ou, conforme Antunes (2009):

(...) há uma crescente imbricação entre trabalho produtivo e improdutivo no capitalismo contemporâneo e como a classe trabalhadora incorpora essas duas dimensões básicas do trabalho sobre o capitalismo, essa noção ampliada nos parece fundamental para a compreensão do que é a classe trabalhadora hoje. (ANTUNES, 2009, p. 104)

Essa noção atual sobre a classe trabalhadora engloba, nesse sentido, todos os sujeitos que vendem sua força de trabalho por um pagamento como forma de sustento de suas necessidades mais básicas, ficando, as cooperativas, sempre dependentes dos atravessadores e da indústria da reciclagem para conseguir se manter ativas economicamente. Portanto, além de incorporar os trabalhadores de indústrias e assalariados, também inclui um novo grupo que surgiu apenas nas relações de trabalho atuais, que é o do trabalhador precarizado, como nos ensina Antunes (2009). 
Ainda de acordo com o autor, desse grupo fazem parte: prestadores de serviços, aqueles que trabalham meio horário ou em grandes cadeias alimentícias, trabalhadores informais, desempregados, dentre outros. Obviamente, estão excluídos dessa classe funcionários de alto escalão com rendimentos elevados, empresários e pequenos e microempreendedores, aqueles que possuem bens e posses acumulados, proprietários rurais etc.

Antunes (2009), diz que, nesse fenômeno da catação e da reciclagem, compreende-se que seus trabalhadores fazem parte da categoria dos improdutivos, uma vez que apenas vendem sua força de trabalho e se encontram no mais baixo nível da rede de produção. Assim, considera-se que os indivíduos trabalhadores desse meio executam um trabalho precarizado, uma vez que possui a catação como quase única alternativa de trabalho e aquisição de renda, nas situações mais adversas de extrema pobreza, para sustento das necessidades mais básicas do ser humano, pois a situação social dos catadores é materializada em condições de trabalhos resultantes da busca constante por estratégias de sobrevivência.

Os catadores de material reciclável são excluídos das relações de trabalho assalariadas formais, ou seja, não possuir nenhuma seguridade social, acaba sendo um fator que dificulta o cotidiano desse trabalhador, no qual o catador acaba sendo privado das condições mínimas de sobrevivência. A ausência do Estado e seus modos de controle social homogeneizadores, em que os trabalhadores informais são empurrados para a marginalização da subalternidade, invisibilizado e converte-se, do ponto de vista do sistema produtor de mercadorias, em mercadorias sem valor, inútil, descartadas, tendo em vista que os materiais recicláveis são coletados nas ruas, lixões das médias e grandes cidades urbanas da periferia mundial, como aponta Antunes (2009).

Portanto, essas mutações que vêm sofrendo o mundo do trabalho, que podem ser consideradas como "Metamorfoses", fomentaram a diminuição daquele proletariado tradicional oriundo dos moldes industriais, ao mesmo tempo em que criaram formas de explorar a mão de obra da classe trabalhadora. Formas que também buscam servir o capital, mas possuem dinâmicas diferentes, com o alargamento das diversas formas precarizadas de trabalho, como a informalidade e a terceirização, gerando o que Antunes (2009) chamou de "heterogeneização, complexificação e fragmentação do trabalho".

Corrêa (1997) compreende 'rede' enquanto uma parte inerente à organização das cidades, desde o mundo mediterrâneo e a baixa idade média. Com as mudanças (não lineares) advindas da modernidade e a consolidação do capitalismo - a organização industrial e a migração acelerada do campo para as cidades -, as redes que antes eram limitadas e facilmente mapeáveis começaram a se estabelecer de modo mais amplo, no sentido interescalar e multiescalar. Ainda, o autor argumenta que, com o capitalismo atual, as redes se estabelecem de maneira complexa em uma trama espaço-temporal, pois, segundo Corrêa (1997), sem o espaço (para que a rede seja materializada) e o tempo (para que se estabeleça um recorte de duração efêmero ou permanente), suas existências tornam-se inviáveis. Em suma, as redes são constituídas por nós (espaciais) que se relacionam a partir de conexões - teias multiescalares - durante determinado período (efêmero ou duradouro).

É possível afirmar que o conceito de 'rede' representa uma esfera geográfica de característica dinâmica e sem previsão de conclusão (assim como o Espaço), conforme argumenta Dias (2000) em diálogo com Claude Raffestin. Nas palavras da autora: “(...) nunca lidamos com uma rede máxima, definida pela totalidade das relações mais diretas, mas com a rede resultante da manifestação das coações técnicas, econômicas, políticas e sociais" (DIAS, 2000, p. 148). 
O autor e a autora supracitados nos dois parágrafos acima, respectivamente, colaboram para a compreensão de que, com os avanços demarcados a partir das configurações atuais do sistema capitalista, que, através do espaço, estabelece-se de maneira bastante dinâmica e aberta, as redes se constituem através das complexas relações sociais - e, como no caso específico deste artigo, também das relações de trabalho. Essas compreensões nos permitem avançar, em diálogo com Ribeiro (2000), através do seguinte trecho:

\begin{abstract}
Quanto mais complexa a divisão do trabalho, o processo de globalização, maior a diversificação e a complexidade dos objetos e das ações. Há um aumento da circulação em decorrência de se produzir mais valores de troca, em função de uma maior especialização. Neste contexto, destacam-se os diversos tipos de redes, que assumem diversas formas de manifestações na organização e expansão do capitalismo, tornando-se, portanto, cada vez mais importantes para a análise geográfica do mundo atual. Nestes termos, todo o processo de transformação por que passa a sociedade capitalista tem como pontos nodais as cidades, onde se encontram e se superpõem valores desiguais. (RIBEIRO, 2000, p. 78)
\end{abstract}

É a respeito deste momento em que as relações sociais instituem-se espacialmente e, por sua vez, constituem redes que correspondem a gama de interesses e necessidades dos sujeitos que compõem essas mesmas relações, em relação às quais argumentamos neste texto. Ainda, o recorte histórico no qual o capitalismo caminha, embora não enquanto uma macroestrutura orgânica, porém como uma instituição organizada socialmente de maneira bastante fluida, relaciona-se à sociedade diretamente ligada a redes de informação de Castells (1999).

O que compreendemos até agora colabora para a noção de que, muito embora as redes se instituam de maneira social, é justamente esta condição que constitui o fato de que, assim como recortes espaciais, as redes também são compostas de maneira desigual em relação às posições dos sujeitos e, por sua vez, a seus papéis, como é o caso da rede de reciclagem recortada para o presente artigo. Tal condição de desigualdade colabora para a reafirmação da sociedade de classes intrínseca ao capitalismo.

Herod et. al (2014), acerca dessa reflexão, colaboram com sua noção a respeito de Global Distruction Networks (Rede de Destruição Global, em livre tradução). Os autores propõem um avanço à compreensão 'clássica' marxista sobre o Sistema de Produção (global), destacando estarem voltados para refletir a respeito da saída de mercadoria final (commodities) e o retorno do resíduo deste produto enquanto uma nova mercadoria a ser renovada (reciclada) e produzida para um novo escoamento. O capitalismo, em sua conjuntura atual, configura-se espacialmente em redes de produção e de destruição, conforme os argumentos dos autores.

Em outras palavras, podemos afirmar que as redes de produção estão relacionadas à cadeia de produção (tradicional) e as redes de destruição à indústria de reciclagem e reaproveitamento de resíduos, ambas interconectadas. De modo geral, Herod et. al (2014) colocam que as GDNs, assim como outras organizações em rede, são compostas por relações sociais específicas, fundamentalmente ao seu funcionamento e, por sua vez, as relações de trabalho que se estabelecem a partir deste recorte, também são atreladas a especificidades próprias, como é o caso da RRERJ.

A noção apresentada até o momento de que as relações de trabalho se estabelecem de maneira interescalar/multiescalar e, obviamente, de maneira espacial, organizadas muitas vezes em rede, como é o caso específico deste estudo, permite com que retornemos ao ponto em que Harvey (2011) coloca o capitalismo enquanto um sistema globalizado e, por sua vez, à noção que já destacamos anteriormente: as 
relações de trabalho sendo interseccionadas de maneira global e local (em um movimento constante). Justamente por estarmos tratando neste momento de uma rede de reciclagem, estamos então abordando uma organização que corresponde à lógica de manutenção da Indústria de Reciclagem e dos Circuitos da Economia de Santos (2008).

Santos (2008) propõe que pensemos o espaço capitalista e as relações de trabalho a partir de 'Circuitos de Produção Econômica', Circuito Inferior e Superior, quando voltamos nossos olhares para fenômenos que ocorrem em sociedades de capitalismo tardio (periférico). Os sujeitos que detêm maior poderio econômico, em geral os proprietários dos meios de produção (como agentes imobiliários, o Estado, os proprietários fundiários e outros indivíduos que compõem classes de renda alta), compõem o circuito superior da economia capitalista. Em detrimento destes sujeitos e, por suposto, deste 'circuito', outros sujeitos constituem posições marginalizadas no espaço capitalista, ou seja, nas relações de trabalho e manutenção do sistema, sendo aqueles os que compõem o circuito inferior, cuja força de trabalho é explorada face à geração de lucro para o circuito superior.

Neste sentido, convém o argumento de que a rede de reciclagem é composta por trabalhadores de catação, constituintes do circuito inferior da economia, porém também por sujeitos que constituem o circuito superior, como os 'atravessadores ${ }^{11}$, e 'empresários', como aponta Gonçalves (2006). Segundo o autor, os atravessadores são responsáveis pela negociação direta dos materiais coletados pelos trabalhadores cujas forças de trabalho são exploradas na prática de catação, o que colabora ainda mais para o tensionamento das relações de trabalho e a marginalização destes sujeitos em relação à indústria de reciclagem, perpetuando suas posições no circuito inferior da Economia.

A justificativa para o hiato na negociação dos materiais coletados entre os trabalhadores da catação e os empresários (indústria de reciclagem) é a escassez de capital monetário dos catadores, condição intrínseca à necessidade de realizar este tipo de trabalho (como demonstraremos na seção seguinte). Esta condição de 'pobreza material' desses trabalhadores é um dos fatores pelos quais estes sujeitos são marginalizados nos mais diversos recortes escalares.

Gonçalves (2006) ainda destaca que a exploração 'forçada' dos atravessadores (sucateiros) para com os catadores se mantém afirmada e aceita, pois se coloca através de um discurso que afirma haver uma 'benfeitoria' do sucateiro em relação aos trabalhadores da catação, omitindo o poder desigual de um em relação a outrem, afirmando que o atravessador colabora na geração de renda do catador, pois seria como um 'cliente' (comprador) do material coletado. Esta compra, no entanto, é efetuada com base em um valor mínimo e que 'pormenoriza' o papel dos catadores.

O autor compreende, assim, que a rede de reciclagem no Brasil (neste caso, no Rio de Janeiro), corresponde diretamente à lógica do sistema capitalista de produção, pois se apoia no desenvolvimento baseado na desigualdade de classes (a produção de lucro em detrimento da miséria da classe trabalhadora) que, neste caso, é significada pela exploração da força de trabalho e do valor do preço do produto coletado pelos trabalhadores que são fundamentais para a existência dessa indústria: os catadores de material reciclável.

O exposto até o momento teve como objetivo destacar os conceitos-chave com os quais o fenômeno que optamos por discutir neste artigo se concentra, a partir das perguntas que fazemos sobre este. Neste sentido, as compreensões sobre espaço e rede, a partir de um recorte do sistema capitalista enquanto um fator preponderante para se compreender as relações de trabalho que ocorrem e alimentam sua lógica e, mais especificamente, constituem a rede de reciclagem do Estado do Rio de Janeiro, sendo 
fundamentais para que possamos prosseguir a respeito das especificidades da RRERJ e, não obstante, a respeito dos catadores de material reciclável.

Assim, a próxima seção tratará de abordar a respeito do trabalho de catação e os trabalhadores envolvidos neste processo, bem como da importância de suas ações e práticas na indústria de reciclagem, sobretudo no Estado do Rio de Janeiro.

\section{Trabalho de catação, catadores de material reciclável da RRERJ e a manutenção da indústria da reciclagem ${ }^{12}$}

$\mathrm{Na}$ introdução deste artigo, destacamos o objetivo geral que propomos enquanto reflexão para este momento. Deste modo, a discussão apontada, a partir da seção anterior, tratou de localizar o fenômeno pesquisado segundo uma abordagem geográfica e, não obstante, a partir dos conceitos que tangenciam tal fenômeno: 'espaço' e 'rede'. Para tanto, após termos realizado um rápido overview dos conceitos supracitados, esta seção tratará de abordar acerca da relação direta destes conceitos com o fenômeno do trabalho de catação: os sujeitos que compõem essa prática enquanto trabalhadores que constituem uma rede (RRERJ) e, por referência, ao objetivo geral: a 'manutenção' da indústria de reciclagem a partir do fundamental trabalho destes sujeitos.

Como destacamos a partir de Harvey (2011), o sistema capitalista de produção tem, enquanto lógica, a geração de lucro e, nas palavras do autor, a manutenção do 'capital constante'. O trabalho de catação de materiais recicláveis está diretamente relacionado a esta lógica quando, a partir da produção exacerbada de materiais de consumo (para escoamento/venda) é intrínseca à geração de resíduos sólidos. $\mathrm{O}$ reaproveitamento e reciclagem destes resíduos ocorre, justamente, pela necessidade de o capitalista utilizar a mesma matéria-prima usada na produção de mercadoria anterior, dada a escassez de recursos (naturais). Diante disso, soma-se o trabalho dos catadores, responsáveis pela coleta de resíduos sólidos urbanos (que, posteriormente, serão negociados com a Indústria).

Rosado (2009) colabora para a compreensão do trabalho de catação, quando afirma que, aliado à 'necessidade' da Indústria em se buscar matéria-prima mais barata e em maior disponibilidade, a partir de materiais de possível reciclagem e/ou reaproveitamento, o labor dos catadores está também relacionado à falta de alternativas de trabalho e, deste modo, trata-se de uma atividade que se apresenta enquanto estratégia de sobrevivência financeira. Essa questão, apontada por Rosado (2009), também é percebida através de uma análise gráfica, realizada a partir dos 3084 questionários aplicados com os catadores, membros da RRERJ, que compõem este trabalho. Quando questionados a respeito de, em caso de haver outras possibilidades profissionais, deixariam de trabalhar com a catação de materiais recicláveis, $66 \%$ afirmaram que 'sim', 33\% optaram por 'não', enquanto outros $2 \%$ não responderam, conforme aponta o gráfico abaixo: 


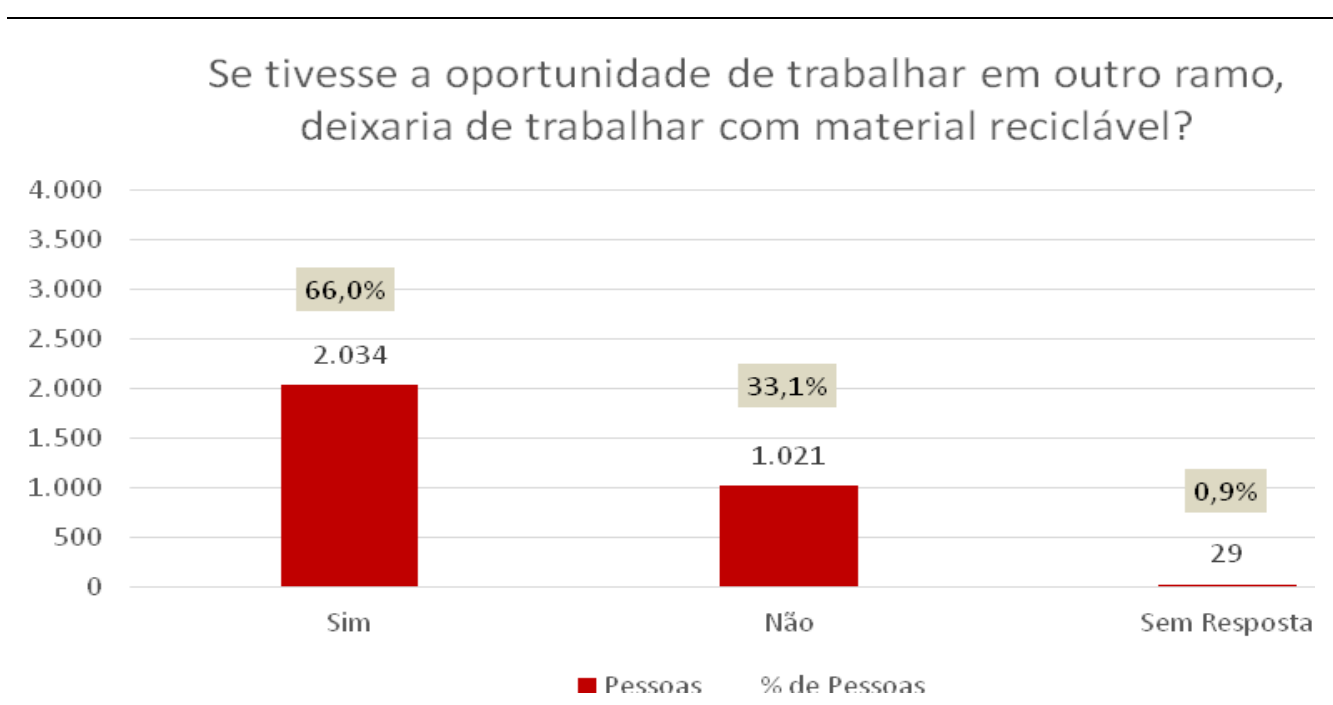

Gráfico 1. Questão: Se tivesse a oportunidade de trabalhar em outro ramo, deixaria de trabalhar com material reciclável?

Fonte: Questionários aplicados pelo autor no projeto CRS - PANGEA - FGV e atualizados via Programa de Computador - CATAsig ${ }^{13}$

Org.: Elaboração própria, (2020)

A realidade demonstrada no gráfico 1 levanta, para além da realidade destes sujeitos que veem na catação de materiais recicláveis sua única oportunidade de sustento financeiro, a necessidade de ilustrar o 'perfil' dos catadores. Segundo Dagnino e Johansen (2017), a maioria dos trabalhadores deste setor são de pessoas mais velhas, em média 39 anos, 2 anos a mais do que trabalhadores do setor formal da economia. Na Rede de Reciclagem do Estado do Rio de Janeiro, a realidade dos catadores é de pessoas com idade ainda mais avançada, como pode ser observado no gráfico a seguir:

\section{Faixa Etária}

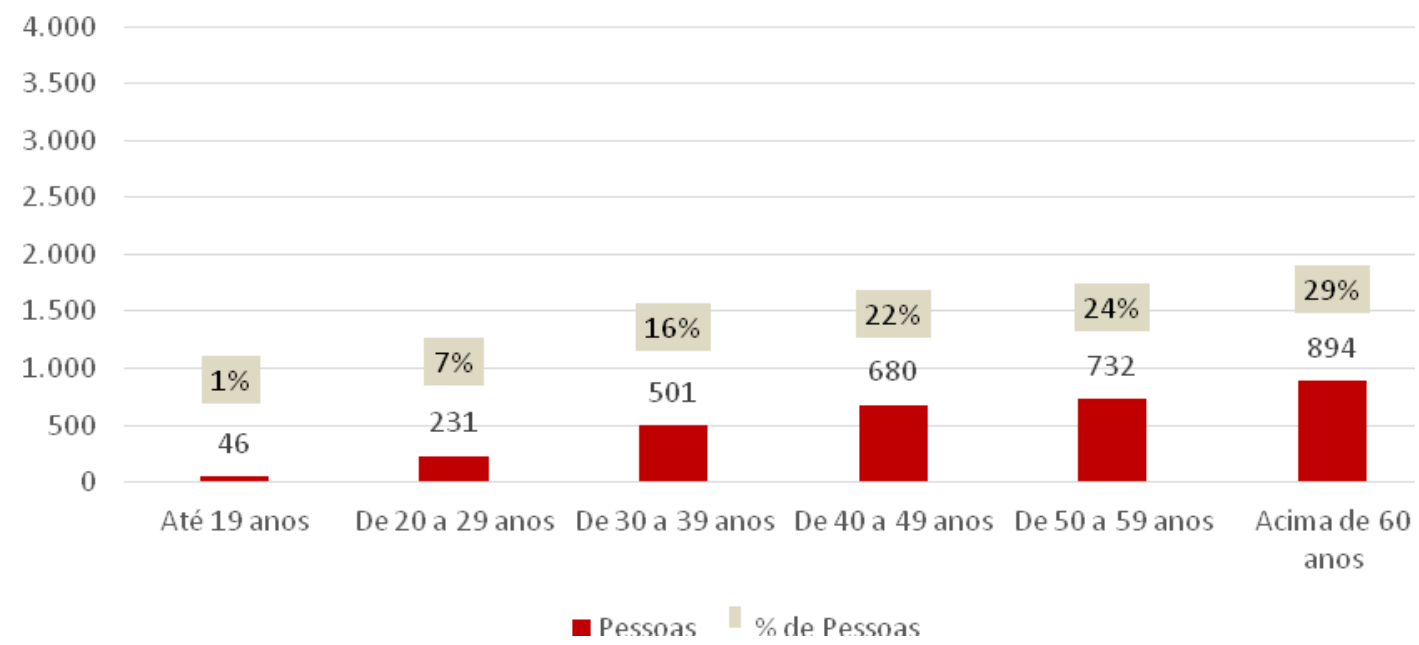

Gráfico 2. Faixa Etária dos Catadores de Materiais Recicláveis da Rede de Reciclagem do Estado do Rio de Janeiro (RRERJ)

Fonte: Questionários aplicados pelo autor no projeto CRS - PANGEA - FGV e atualizados via Programa de Computador - CATAsig

Org.: Elaboração própria, (2020) 
A correlação entre os dois gráficos demonstra a intersecção entre os dois fatores. Ora, se os trabalhadores da RRERJ têm suas idades majoritariamente distribuídas entre 30 e mais de 60 anos, fica clara a dificuldade da reinserção desses sujeitos em outros postos de trabalho no setor formal, colocando-os sob as condições da informalidade e, portanto, da reciclagem.

De modo geral, no gráfico abaixo, observa-se que a maior parte das profissões precedidas àquela de catador continuava na esfera do trabalho doméstico ou de baixa especialização, vinculados ao circuito informal. De fato, somando-se as atividades respondidas como "costurava em casa", "fazia bicos, "não trabalhava" e "dona de casa", obtemos um montante de $50 \%$ de pessoas cuja profissão anterior era também vinculada à esfera da informalidade. Se adicionarmos as atividades de construção civil e comércio, esse índice alcança 64,1\%. Ou seja, pode-se inferir que essas pessoas vêm de uma trajetória de informalidade na sua vida laboral, em que a catação é mais uma atividade de um circuito marcado pela estratégia da sobrevivência.

Também é possível observar um expressivo percentual de ofícios anteriores exercidos por mulheres, o que pode ser resgatado pela somatória dos índices representados por respostas como "costurava em casa" e "dona de casa", que totaliza $24,9 \%$, devendo ser esse índice ainda maior, tendo em vista que nas outras atividades não é possível detectar o gênero.

No geral, o catador de materiais recicláveis é um profissional de pouquíssima ou quase nenhuma especialização profissional. Podemos notar isso de acordo com o gráfico que as profissões anteriores necessita de alguma especialização ou algum conhecimento prévio, pois a catação de materiais recicláveis exige que o catador esteja disposto a percorrer o espaço geográfico, triar por uma experiência de conhecimentos dos materiais muito primária, na qual ele tria os materiais de maior valor e cata o máximo que seu big bag ou carrinho possa comportar.

O gráfico abaixo ilustra que, em geral, os catadores de materiais recicláveis ocupavam outros postos profissionais anteriormente ao ofício atual e, deste modo, podese estreitar ainda mais a relação entre os gráficos 1 e 2 , sobre faixa etária e a (não) opção do trabalho com reciclagem:

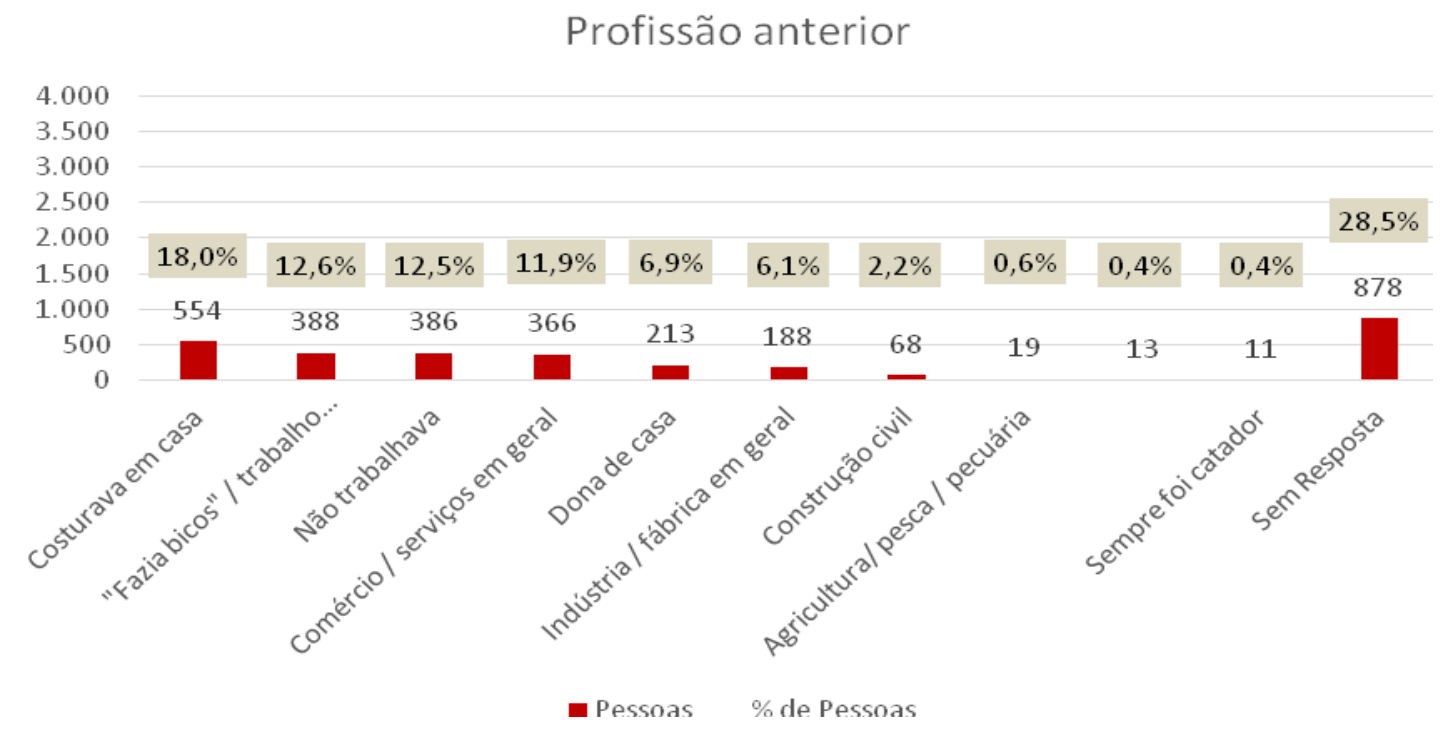

Gráfico 3. Profissão anterior ao ofício de Catador de Materiais Recicláveis

Fonte: Questionários aplicados pelo autor no projeto CRS - PANGEA - FGV e atualizados via Programa de Computador - CATAsig

Org.: Elaboração própria, (2020) 
Como destacado, enquanto uma possibilidade dentro de uma escala de possibilidades limitadas de sustento financeiro, ainda podemos dialogar com a Rosado (2009), que destaca que esses trabalhadores constituem uma realidade de grande exposição ao ciclo de exploração, colocando-os em condição de marginais em uma rede social de relações que envolve a reciclagem, como é o caso da rede que tratamos neste artigo.

Assim como a autora, acerca do trabalho da catação e seu papel na indústria da reciclagem, Pereira et. al (2016) colaboram sobre o impacto dessa indústria na economia brasileira, ainda sobre a relação dessa indústria com o mercado nacional, como também com as indústrias de exportação. $\mathrm{O}$ que os autores destacam se refere ao fato de que a prática da reciclagem constitui um importante papel, enquanto um componente da segurança econômica do país, quando do destaque do principal material que compõe este setor: a sucata de alumínio. Esse dado refere-se ao fato de que o valor pago para este tipo de material é bastante superior aos outros tipos de sucata, tais como papel e plástico e, para além, outro dado é de que, desde antes de meados de 2000, o Brasil dominava $90 \%$ do mercado mundial, no tocante à reciclagem de alumínio e, a partir de 2005, alcançou 95\% deste mercado, representando uma relação direta entre a compra da sucata e o comércio do alumínio reciclado.

Por outro lado, embora seja um importante componente da economia brasileira, a Indústria da Reciclagem, assim como as outras, traduz, em sua estrutura, através das relações dos sujeitos envolvidos em seu funcionamento, uma ampla desigualdade social. Essa afirmação, ainda em diálogo com Pereira et. al. (2016), justifica-se, pois o valor de repasse à base da rede de reciclagem, que se constitui dos catadores de material reciclável, é bastante baixo. Isso ocorre devido ao grande valor absorvido pelos autores que constituem a rede em posições de poder mais concentrado, como os atravessadores (sucateiros) e os empresários.

A profunda desigualdade marcada nessa indústria é materializada quando das condições em que os trabalhadores se encontram. Uma das condições a ser assinalada é a de moradia. Ao serem questionados sobre quantos cômodos cada um dos catadores possuíam na casa em que residiam, a maioria apontou de 2 a 5 cômodos, sendo a maior parte entre 3 e 4 cômodos, conforme ilustrado no gráfico abaixo:

\section{Cômodos no domicílio}

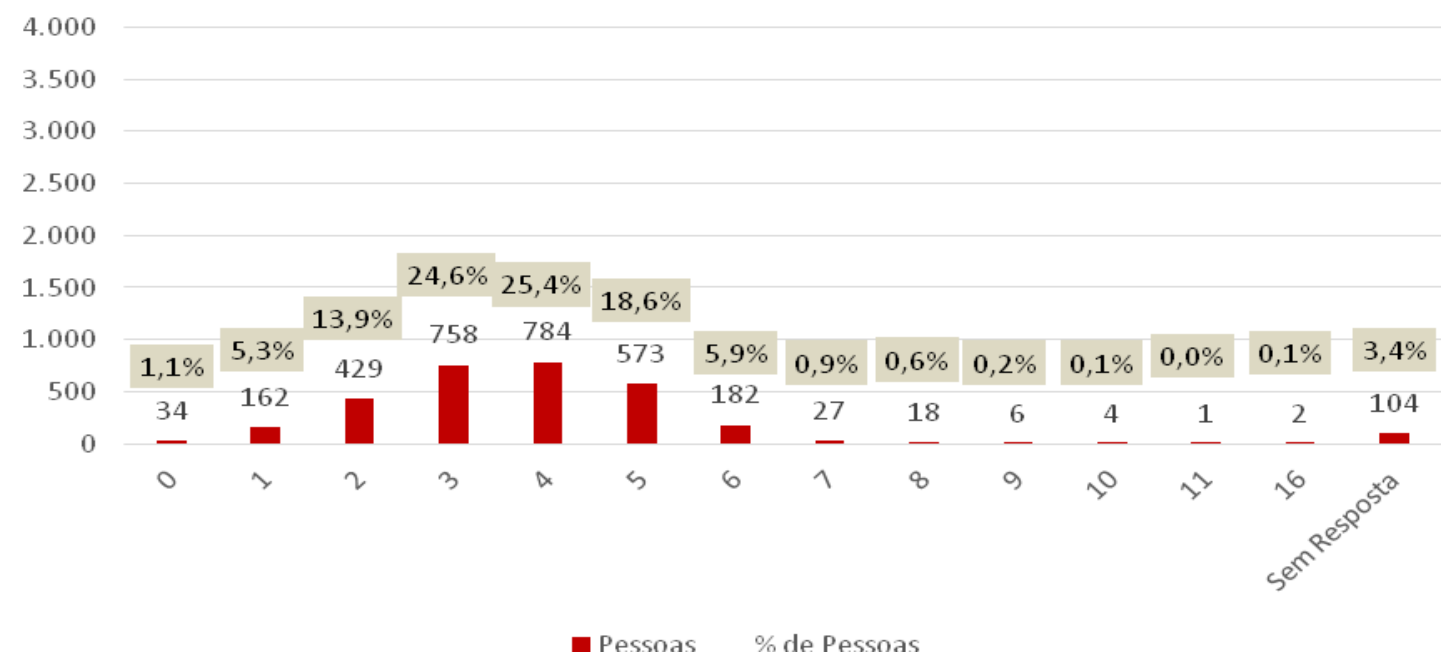

Gráfico 4. Quantidade de cômodos por domicílio dos Catadores de Materiais Recicláveis de RRERJ Fonte: Questionários aplicados pelo autor no projeto CRS - PANGEA - FGV e atualizados via Programa de Computador - CATAsig - Org.: Elaboração própria, (2020) 
No que se refere aos cômodos para dormir, a maior parte dos catadores segue as condições que marcam a pobreza urbana no Rio de Janeiro e sua região metropolitana. De fato, $63 \%$ das famílias dos catadores possui apenas 1 cômodo para dormir, sendo que $46,1 \%$ das famílias possuem mais de 4 pessoas dormindo no mesmo cômodo. Essa situação supracitada se justifica pela questão mais crítica da especulação imobiliária e elevado custo do metro quadrado na Região Metropolitana do Rio de Janeiro nas comunidades, onde o crescimento habitacional é basicamente vertical, tendo em vista a densidade habitacional.

É importante destacar que, em conjunto com o gráfico 4, quando questionados dos cômodos de suas residências utilizados para dormir, a massiva maioria apontou que apenas 1 cômodo da casa é utilizado para este fim, conforme pode ser observado no gráfico 5:

\section{Cômodos usados para dormir}

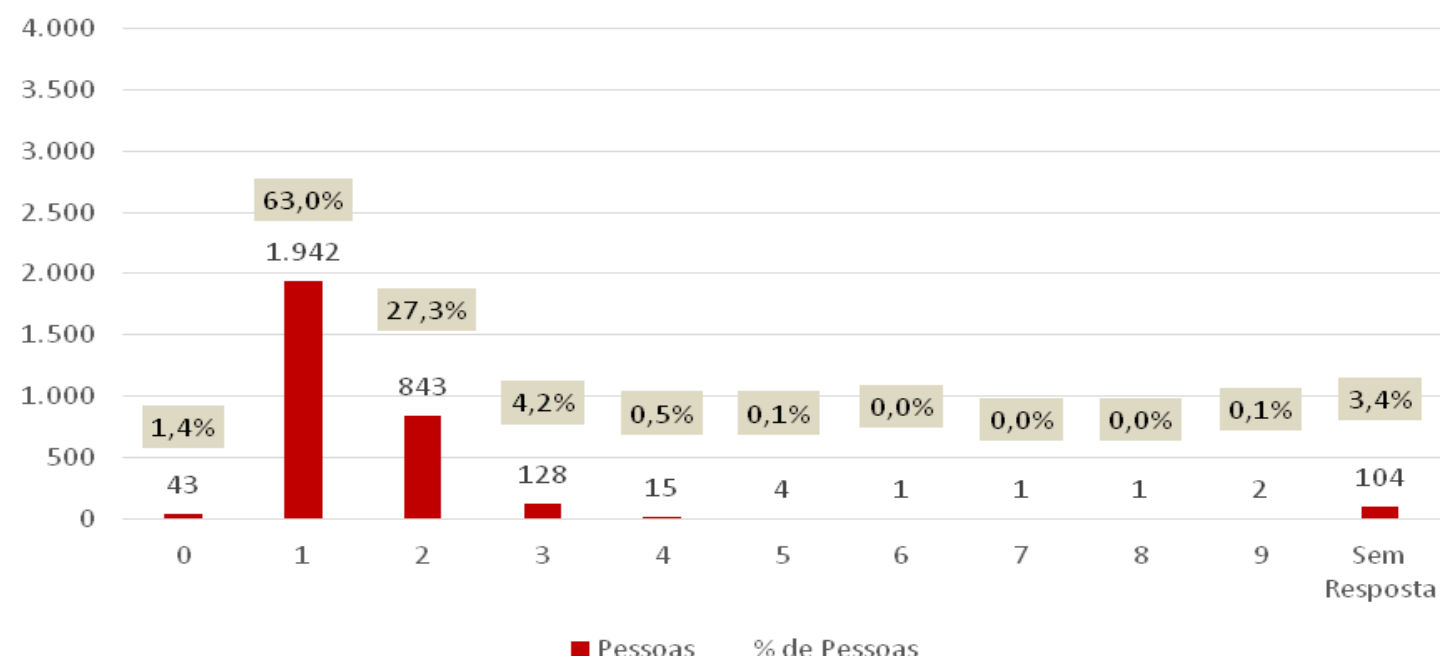

Gráfico 5. Quantidade de cômodos por domicílio utilizados para dormir pelos Catadores de Materiais Recicláveis de RRERJ

Fonte: Questionários aplicados pelo autor no projeto CRS - PANGEA - FGV e atualizados via Programa de Computador - CATAsig

Org.: Elaboração própria, (2020)

Para além, um dado importante que também cabe ser utilizado nesta relação é o fato desses domicílios, além de apresentarem uma carência quanto à estrutura doméstica e ao conforto que traga dignidade ao sujeito, como, por exemplo, a falta de cômodos utilizados para um fim específico - como um quarto -, o espaço doméstico é também utilizado para fins de armazenagem ${ }^{14}$ de material coletado $36,7 \%{ }^{15}$, o que é bem expressivo e preocupante, pois já são moradias pequenas, geralmente, $30\left(\mathrm{~m}^{2}\right)$ no máximo, com poucos cômodos, para os quais os catadores levam possíveis contaminações para os seus familiares. Os catadores acostumam-se também a não armazenar em seu domicílio $24,9 \%$, o que podemos supor que ele cata e já vende rapidamente para um atravessador ou uma cooperativa de fachada ${ }^{16}$, na tentativa de levar um sustento rápido para seus familiares, como segue o ilustrado: 


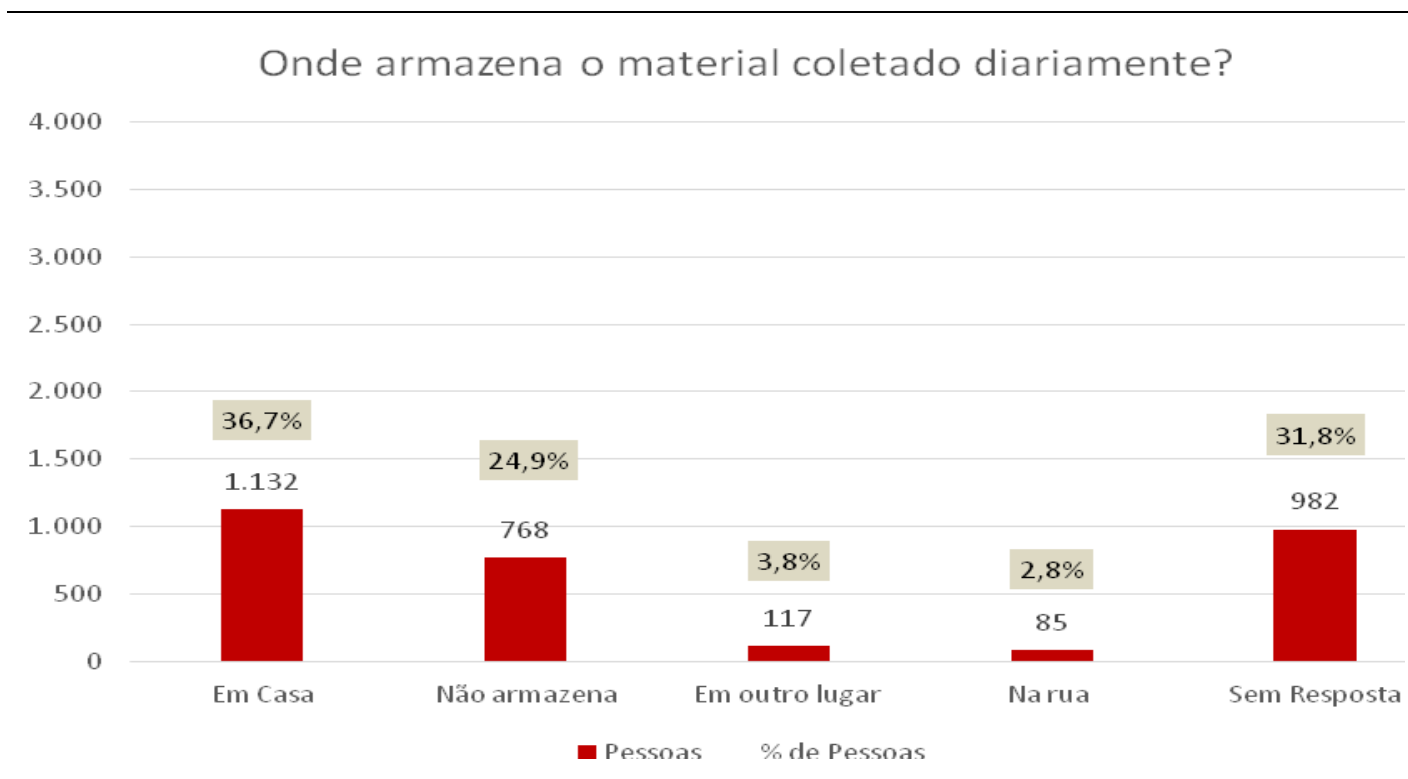

Gráfico 6. Local de armazenagem de materiais coletados pelos Catadores de Materiais Recicláveis da RRERJ

Fonte: Questionários aplicados pelo autor no projeto CRS - PANGEA - FGV e atualizados via Programa de Computador - CATAsig

Org.: Elaboração própria, (2020)

A condição de vulnerabilidade social e, por sua vez, econômica, na qual os catadores de materiais recicláveis se encontram, como demonstrado nos gráficos acima, é um meio pelo qual o capitalismo mantém-se estruturado. O gráfico 6, especificamente, ilustra a vulnerável condição na qual esses trabalhadores se encontram que, na ausência de local adequado para a separação de materiais, (re)espacializam suas residências para este fim. É nessa condição de miserabilidade econômica que o capitalismo institui seu ciclo de acumulação de capital constante- Harvey (2011).

Esses apontamentos nos permitem avançar em diálogo com Costa e Chaves (2012), que destacam que o trabalho de catação está intrinsecamente ligado à configuração atual do sistema capitalista, o que ainda colabora com a afirmação de que a reciclagem é um componente direto da manutenção deste sistema, na escala da indústria da reciclagem, como também na relação dessa indústria com outras.

Essa ligação direta com o capitalismo contemporâneo é defendida a partir do argumento dos autores de que, no Brasil, essa prática teve um aumento de aproximadamente $240 \%$, quando referente aos catadores de materiais recicláveis, entre os anos de 1995 e 2005. Em suas palavras, esse grande número de catadores garante "a sustentabilidade do processamento industrial dos materiais, conferindo maior ganho via exploração do trabalhador, diminuição do uso de matérias-primas, economia de energia e, consequentemente, maximização dos lucros" (COSTA E CHAVES, 2012, p. 03).

Neste sentido, o posto desses profissionais, enquanto sujeitos componentes de uma rede de reciclagem, coloca-se enquanto o mais frágil dentre outros postos, representando a base de uma pirâmide que compreende outros sujeitos que, hierarquicamente (em ordem crescente), colocam-se da seguinte forma: catadores compradores - atravessadores (sucateiros) - empresários. Dentro disso, Costa e Chaves (2012) argumentam que as condições organizacionais e de trabalho dos profissionais da catação se estabelecem enquanto bastante precárias e em uma busca constante pela sobrevivência financeira.

Conforme o exposto até o momento, podemos afirmar que há fragilidades acerca da situação de trabalho e ganho (monetário) dos catadores de material reciclável, 
sobretudo quando relacionamos a posição dos mesmos em relação aos outros sujeitos que compõem a rede de reciclagem e estes, por sua vez, quando se relacionam à indústria de reciclagem (e outras indústrias aqui não abordadas, somada à lógica capitalista).

No entanto, é válido o argumento de que, muito embora a super exploração destes trabalhadores os coloque enquanto marginais nas interrelações com outros sujeitos desta rede, é fundamental e, não obstante, primordial, seus papéis em relação à manutenção das lógicas do capitalismo (e da Indústria de Reciclagem). Tal importância está relacionada ao fato de que, sem esses sujeitos, não há acesso ao material coletado para os demais sujeitos que constituem a rede de reciclagem, conforme apontam Costa e Chaves (2012).

Destarte, a rede de reciclagem do Estado do Rio de Janeiro corresponde à mesma lógica apontada pelos autores com os quais estabelecemos diálogo até o momento, pois as assimetrias de poder presentes na relação entre os sujeitos, os quais, por suposto, marginalizam os principais sujeitos que mantêm o funcionamento da rede, porém, ainda assim, os catadores de materiais recicláveis se colocam presentes e colaboram com a geração de lucro da Indústria da Reciclagem, baseada na exploração da força de trabalho desses sujeitos, havendo, ainda, a precarização do trabalho e o valor irrisório pago pelos materiais coletados por estes trabalhadores.

A indústria da reciclagem relacionada à rede de reciclagem do Estado do Rio de Janeiro é, deste modo, perpassada pelo trabalho dos catadores que, através dessa rede, imprimem espacialmente suas trajetórias justificadas pelo deslocamento entre locais de coleta e de venda do material (para os compradores e/ou intermediários/sucateiros). Por fim, a destinação final das coletas de materiais recicláveis realizadas pelos diversos atores e sujeitos podem ser verificadas na imagem abaixo e no anexo:

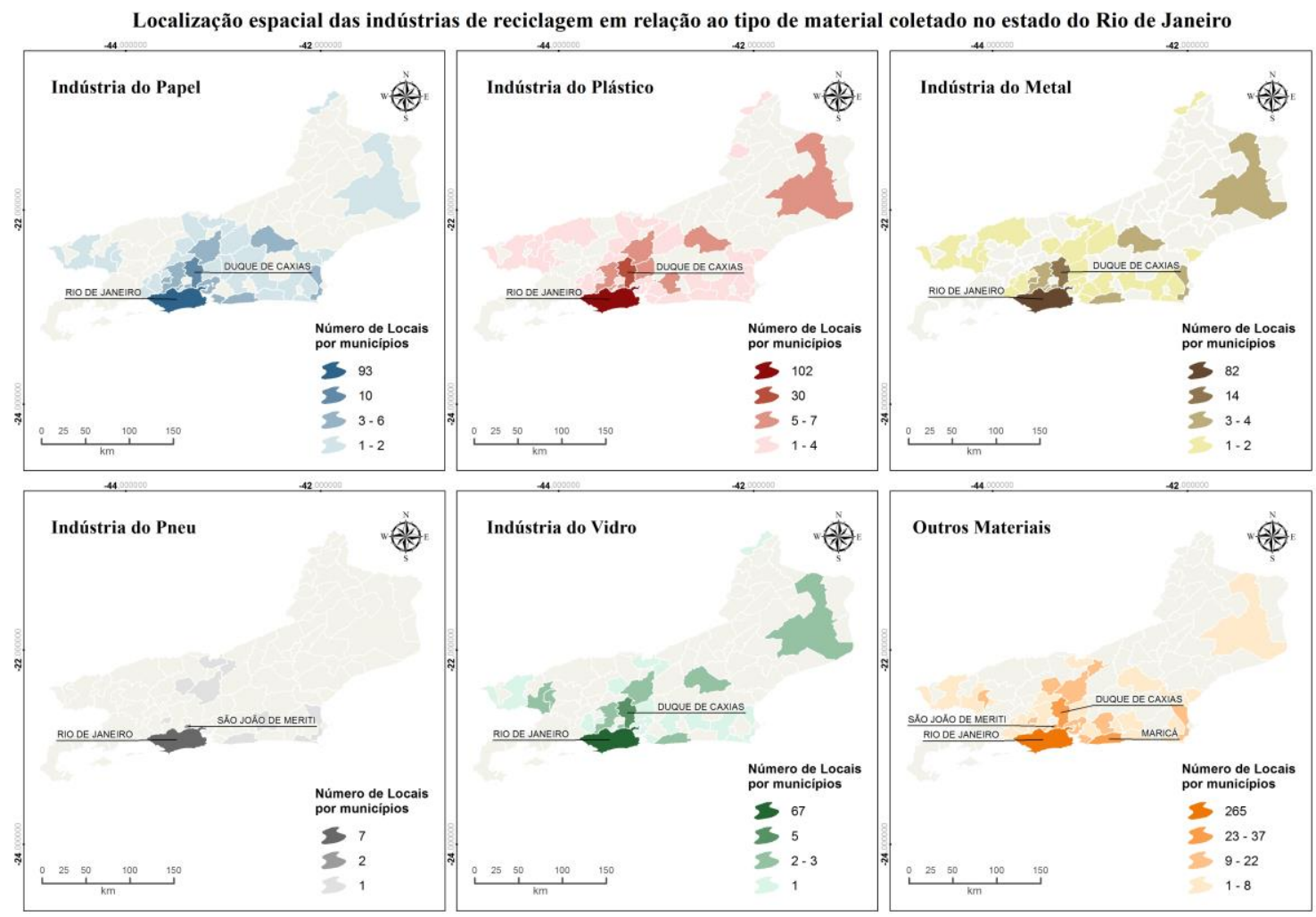

Imagem 1. Cartogramas da localização espacial das indústrias de reciclagem em relação ao tipo de material coletado no estado do Rio de Janeiro.

Fonte: Levantamento realizado pelo autor, (2020). Org.: Elaboração própria, (2020). 
Os materiais coletados e, posteriormente, negociados com os outros sujeitos que compõem a rede, serão encaminhados aos outros componentes (empresários proprietários dos meios de produção) com novos valores (acrescidos da margem de lucro resultante da exploração da força de trabalho dos catadores, com baixos valores pagos aos produtos de coleta). Sendo assim, os cartogramas acima evidenciam o grande número de pontos de coleta relacionados aos materiais e o importante papel desses sujeitos na manutenção dessa indústria.

O ônus resultante à classe trabalhadora que corresponde aos catadores é justamente o da não valorização de seus papéis enquanto fundamentais nessa indústria e, por suposto, na manutenção do sistema capitalista de produção. Nas páginas anteriores, demonstramos um gráfico que traduzia o principal motivo da realização dos trabalhos por esses sujeitos, enquanto sendo a escassez de outras oportunidades profissionais. A desvalorização da força de trabalho, o valor baixo pago aos materiais coletados, bem como outras questões que significam a precariedade dessa prática laboral, reforçam ainda mais a relação marginal dos catadores na RRERJ e materializa o paradoxal papel dessa prática de trabalho como fundamental na rede e, por suposto, na indústria, embora seja aquela a responsável pela posição marginal destes sujeitos.

A relação entre o recorte específico deste artigo e as discussões gerais a respeito da importância do trabalho de catação na lógica da reciclagem de resíduos sólidos e, por sua vez, na indústria de reciclagem, através das redes organizadas espacialmente e, neste caso, no Estado do Rio de Janeiro, apresentada nesta seção e alimentada pelos conceitos apresentados na seção anterior, correspondem justamente à proposta apresentada no objetivo geral deste texto.

É factual a importância dos catadores de material reciclável na manutenção da indústria de reciclagem e, inclusive, na ordem do sistema capitalista de produção. No entanto, os custos resultantes à classe trabalhadora, principal componente desta lógica, é em demasia alto. No início deste artigo, os argumentos de Harvey (2011) sobre o sistema capitalista foram apresentados e nortearam todo o desenvolvimento dessa reflexão. O que o autor demonstra, assim como o que procuramos dialogar com outros autores e autoras corroboram na compreensão geral acerca da desigualdade no capitalismo contemporâneo e, para além, como tal sistema é retroalimentado por esta lógica desigual.

A RRERJ é uma instituição a partir de relações sociais de diversos sujeitos e suas especificidades. As práticas perpassadas por estas relações de poder colaboram para a alimentação da lógica capitalista e esta corresponde à super exploração dos catadores de material reciclável do Estado do Rio de Janeiro e à marginalização desses sujeitos, configurando a instituição destes no circuito inferior da economia- Santos (2008).

O caminho escolhido para a compreensão desse fenômeno colabora para que compreendamos a prática de catação enquanto o principal 'meio' para o acúmulo de capital constante na indústria de reciclagem, em que os sujeitos que se posicionam centralmente perpetuam a concentração desigual de renda, em relação aos marginais (catadoras[es]). Essa lógica intrínseca ao sistema capitalista precariza as condições de trabalho e condiciona os sujeitos (sobretudo os que nos referimos nesta reflexão) a postos de trabalho perpassados pela invisibilidade e não reconhecimento, muito embora dependa diretamente desses sujeitos para sua constante permanência. 


\section{Considerações Finais}

Propusemos para este artigo uma compreensão acerca do trabalho de catação enquanto um componente da manutenção da indústria de reciclagem, realizado a partir dos catadores de materiais recicláveis, pertencentes à rede de reciclagem do Estado do Rio de Janeiro.

Deste modo, concentramos a reflexão a partir de duas seções, nas quais buscamos inicialmente apresentar e discutir os conceitos-chave elencados a partir do objetivo geral, espaço e rede, relacionando-os com o sistema capitalista de produção e sua lógica específica que, segundo Harvey (2011), constitui-se do acúmulo de capital constante. Por conseguinte, a segunda seção tratou de abordar a respeito do trabalho específico de catação de materiais recicláveis, a importância dos trabalhadores envolvidos nessa prática, suas relações com a RRERJ e, por suposto, como objetivado, na composição direta da indústria de reciclagem.

O espaço, enquanto conceito-chave, foi apresentado, segundo as perspectivas de Corrêa (2000), Massey (2008) e Souza (2013. Embora os autores e a autora tenham compreensões que, em alguns momentos, destacam-se enquanto diferentes, é necessário que se coloque a similaridade entre suas reflexões, principalmente no que tange a respeito do entendimento do espaço enquanto um construto social e constituído de relações sociais. Este ponto possibilita um olhar a respeito do fenômeno que aqui analisamos, enquanto espacial e, por sua vez, dinâmico, em que as relações dos sujeitos são perpassadas por especificidades atreladas ao recorte da rede de reciclagem e, não obstante, pelas relações de trabalho constituídas nessa rede.

Neste sentido, a rede se estabelece também enquanto um construto social e, segundo os argumentos apresentados, é constituída a partir da comunicação entre os indivíduos e, por meio desta, estabelecem-se arestas, que se materializam em nóspontos de 'encontro' dessa rede na qual cada indivíduo ou grupo de indivíduos se estabelecem segundo seus papéis.

Tanto o espaço como a rede, neste recorte, correspondem ao sistema capitalista de produção - como apresentado ao longo do texto. Esta afirmação nos permite inferir que a rede de reciclagem do Estado do Rio de Janeiro é constituída por relações de trabalho que se estabelecem de maneira desigual, nas quais os sujeitos fundamentais para a existência desta rede- os catadores de materiais recicláveis- são colocados à condição de marginais, intrínsecos ao circuito inferior da economia- Santos (2008).

É importante destacar que a RRERJ é composta, como demonstrado, não só por catadores, como também por compradores, atravessadores (sucateiros) e empresários. Esses outros sujeitos componentes da rede constituem posições mais centrais em relação aos catadores, muito embora a 'base' da pirâmide que se constitui nessa trama seja composta por estes trabalhadores. A posição desses sujeitos enquanto os maiores explorados desse recorte corresponde justamente à lógica de geração de lucro para os sujeitos centrais da indústria de reciclagem, conforme argumentaram Costa e Chaves (2012).

Ainda, em diálogo com Pereira et. al (2016), compreendemos que a indústria de reciclagem é uma das principais que colaboram na manutenção da segurança econômica nacional, devido ao grande número de reciclagem de alumínio, tanto para o mercado interno, como para exportação. Esse fato é alimentado de acordo com o fornecimento de material reciclável coletado através do labor dos catadores de material reciclável.

A prática de catação de materiais recicláveis é um importante meio de geração de renda para um recorte populacional afetado pela escassez de outros postos 
profissionais no mercado de trabalho. Para além, corresponde a uma prática que colabora para a preservação do meio ambiente. No entanto, no que toca à proposta desta reflexão, esse labor é um importante componente da indústria de reciclagem, quando da força de trabalho explorada dos sujeitos que compõem essa indústria, enquanto 'fornecedores' de material coletado e que, posteriormente, passará por um processo de reciclagem e venda enquanto matéria-prima 'renovada' para outras indústrias.

Este trabalho é perpassado pela desvalorização desses sujeitos, pois os valores pagos pelos materiais coletados são irrisórios. Esta condição está relacionada à negociação com os 'compradores' e 'atravessadores', que concentram suas rendas com base na diferença do valor pago pelo material e o valor de venda deste para os empresários da Indústria. Tal condição fragmenta ainda mais as relações de trabalho e intensificam a marginalização dos catadores de materiais recicláveis que, por estratégia de sobrevivência, buscam sustento nessa prática.

Para 'não' concluir, este trabalho teve como objetivo colaborar com um olhar específico sobre o fenômeno da reciclagem e a relação direta com o trabalho de catação. Longe de afirmar que apresentamos neste artigo uma única verdade acerca da vivência dos 'sujeitos da catação', esta perspectiva corresponde aos dados coletados, a partir dos 3084 questionários aplicados com o grupo, bem como a correspondência desses dados com a literatura específica que busca 'responder' a este fenômeno em uma perspectiva científico geográfica, sobretudo brasileira.

\section{Notas}

1 - Palavras iniciais, A relação entre o trabalho dos catadores de materiais recicláveis da rede de reciclagem do estado do Rio de janeiro e a manutenção da indústria da reciclagem. O presente artigo faz parte da pesquisa "A produção social do trabalho na rede de reciclagem no estado do Rio de Janeiro" em andamento no curso de Doutorado em Geografia - Programa de Doutorado em Geografia, do Instituto de Geociências da Universidade Federal de Minas Gerais, na linha de pesquisa - Produção do espaço, ecologia, política, cultura, educação em Geografia.

À FAPEMIG pela concessão de bolsa de pesquisa.

2 - O conceito de 'rede', um dos conceitos-chave da Geografia, será mais bem abordado ao longo do desenvolvimento deste artigo.

3 - A discussão referente aos conceitos de 'circuito superior' e 'circuito inferior' da economia será mais bem debatida no decorrer do trabalho. No entanto, vale o destaque de um referencial base para a compreensão acerca dos mesmos, presente em Santos (2008), no livro 'O Espaço Dividido'.

4 - Válido afirmar que a RRERJ não é composta apenas por catadores de material reciclável, porém também de outros sujeitos. No entanto, os catadores de material reciclável têm fundamental importância na existência dessa rede, como também na manutenção da indústria da reciclagem, como demonstraremos ao longo do texto.

5 - O questionário foi baseado no método de pesquisa do Instituto Brasileiro de Geografia Estatística (IBGE), que leva em consideração a autodeclaração da população negra, dividida entre pretos e pardos, sendo, nesta pesquisa, respectivamente, 1439 pardos e 748 pretos.

6 - Levamos em consideração a perspectiva de Hall (2011) que define a 'identidade' enquanto um construto social, uma faceta cultural intersubjetiva e relacional. Discutiremos, de maneira mais qualitativa, o conceito adiante.

7 - Para o desenvolvimento do relatório, pude participar tanto como funcionário em sua execução quanto da criação do sistema destinado a compilar as informações coletadas 
na pesquisa, gerando mapas e arquivos de dados. Contamos, também, com a colaboração de 40 (quarenta) recenseadores, que estiveram encarregados de realizar as visitações aos catadores de materiais recicláveis, realizando as devidas entrevistas presenciais com estrutura fechada. Neste trabalho, com duração de 6 (seis) meses, foram utilizados, como recurso metodológico, aparelhos de Global Positioning System - GPS, a fim de obter precisão quanto à localização de cada um dos catadores. Atualização realizada via software CATAsig, desenvolvido pelo autor.

8 - Óleos e Gorduras Residuais - OGR.

9 - Para uma maior profundidade em relação às especificidades às quais me refiro neste parágrafo, é recomendável a leitura da obra de Harvey (2011), "O enigma do capital: e as crises do capitalismo", apresentado nas referências deste artigo.

10 - Não apenas a partir da condição de 'catadores de material reciclável' esses sujeitos vivenciam seus cotidianos, porém também através de outros marcadores culturais que serão expostos na segunda subseção.

11 - Gonçalves (2006) também denomina os 'atravessadores' como 'sucateiros'.

12 - As condições normais de vida, moradia, trabalho dos catadores de materiais recicláveis comprovadas através das pesquisas e gráficos deste artigo. Podemos afirmar que se agrava em tempos de COVID-19, inclusive, os catadores são do grupo de risco, de acordo com a Organização Mundial da Saúde - OMS e Ministério da Saúde do Brasil, na qual os catadores estão pleiteando e recebendo o auxílio emergencial e doação da sociedade civil. De acordo com o Recicleiros (2020), é de suma importância em épocas de pandemia que esta prática cotidiana de armazenamento de materiais em casa seja banida. E algumas recomendações sobre o manuseio, higiene pessoal, equipamentos de proteção individual, e armazenamento são adotadas cotidianamente. Para conhecimento do manual de boas práticas para catadores em atividade, consulte $<$ https://recicleiros.org.br/boaspraticas/> acessado 29 de abril de 2020.

13 - Software desenvolvido e registrado pelo autor - Instituto Nacional da Propriedade Industrial - INPI, Número do registro: BR512013000238-9 - Implementado através do Projeto Catadores e Catadores em Rede Solidária do Estado do Rio Janeiro, Secretaria do Ambiente, Governo do Estado do Rio de Janeiro e Governo Federal.

14 - O trabalho nas cooperativas e dos catadores agravam em tempos de COVID-19 em termos de armazenamentos de forma geral, pois os mesmos não estão encontrando facilidade de venda e escoamento dos materiais e consequentemente acabam armazenando mais materiais recicláveis nas cooperativas e suas residências, o que pode ocasionar no um futuro próximo uma escassez de embalagens por parte da indústria recicladora. Sem contar que os materiais recicláveis estão em processo de quarentena de 24 horas de forma geral, ou seja, todos os materiais recicláveis. Acessado 04 de maio de $2020<$ https://g1.globo.com/pr/parana/noticia/2020/04/03/lixo-reciclavel-passa-a-ficarem-quarentena-de-24-horas-antes-de-ser-separado-por-catadores-em-curitiba.ghtml .

Acessado 05 de maio de $2020<$ https://blog.eureciclo.com.br/2020/04/voce-sabe-comoo-covid-19-esta-afetando-cadeia-de-reciclagem/>.

15 - Algumas das recomendações em tempos de COVID-19. indo pra casa, se possível, tome banho e troque de roupa no trabalho; use máscara, no trajeto até a sua casa; deixe sapatos e botas sujas do lado de fora; vá direto para o banho e use roupas limpas em casa. Em relação aos materiais, antes da triagem, mantenha os que chegaram da coleta em repouso por 72 horas; A importância de a sociedade em geral higienizar seus materiais recicláveis e colocar os mesmos em sacolas para o devido descarte nas lixeiras residências.

16 - Cooperativa de fachada, coopergatos ou cooperfraudes são falsas cooperativas que hoje infestam o país, são empreendimentos capitalistas que simplesmente pagam aos 
seus trabalhadores, pro forma "seus sócios", apenas o salário direto, ou seja, o dinheiro que o trabalhador leva para casa. Hoje os chamados encargos indiretos representam algo próximo da metade do pagamento total que os trabalhadores recebem dos seus empregadores. Então, é extremamente sedutor para um empresário transformar a sua firma numa pseudocooperativa e praticamente reduziu pela metade o seu gasto com a folha de pagamentos. Existem hoje até consultoras especializadas em transformar empresas em falsas cooperativas. Paul Singer (2008).

\section{Referências bibliográficas}

ANTUNES, Ricardo. Os Sentidos do Trabalho: Ensaio sobre a afirmação e a negação

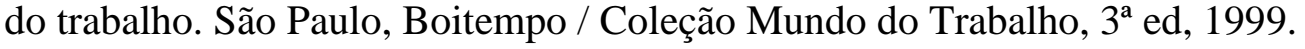

CASTELLS, Manuel. Prólogo: A Rede do Ser. In: CASTELLS, Manuel. A Sociedade em Rede. São Paulo: Paz e Terra, 1999, p. 39 - 66.

CORRÊA, Roberto Lobato. Dimensões de Análise das Redes Geográficas. In: CORREAA, Roberto Lobato. Trajetórias Geográficas. Rio de Janeiro: Bertrand Brasil, 1997, 3ª Ed., p. $107-118$.

Espaço, um conceito-chave da Geografia. In: Geografia:

Conceitos e Temas. ORG: CASTRO, Iná Elias de. et Al. Rio de Janeiro: Bertrand Brasil, 2000, $2^{\text {a }}$ Ed., 356 p.

COSTA, Wesley Borges da.; CHAVES, Manoel Rodrigues. Informalidade e Precarização do Trabalho de Catação de Materiais Recicláveis no Brasil: Pontos para debate. In: XII Jornada do Trabalho - "A irreformabilidade do capital e os conflitos territoriais no limiar do século XXI. Os novos desafios da Geografia do Trabalho". Presidente Prudente: UNESP, 2012. 12 p.

DAGNINO, Ricardo de Sampaio; JOHANSEN, Igor Cavallini. Os catadores no Brasil: características demográficas e socioeconômicas dos coletores de material reciclável, classificadores de resíduos e varredores a partir do Censo Demográfico de 2010. In: BRASIL, Instituto de Pesquisa Econômica Aplicada; BRASIL, Ministério do Trabalho. Mercado de Trabalho: Conjuntura e Análise. 2017. P. 115 - 125.

DIAS, Leila Christina. Redes: Emergência e Organização. In: Geografia: Conceitos e Temas. Org.: CASTRO, Iná Elias de. et. al. Rio de Janeiro: Bertrand Brasil. 2000, 2 Ed. $356 \mathrm{p}$.

GONÇALVES, Marcelino Andrade de. O Trabalho no Lixo. Presidente Prudente, 2006. (Doutorado em Geografia). Programa de Pós-Graduação em Geografia. FCTUNESP, Presidente Prudente - SP, 310 p., 2006.

HARVEY, David. Condição Pós-Moderna: uma pesquisa sobre as origens da mudança cultural. $17^{\mathrm{a}}$ Ed. São Paulo: Loyola, 2008. 349 p.

Boitempo, 2011. 235 p.

O enigma do capital: e as crises do capitalismo. São Paulo:

HEROD, Andrew.; PICKREN, Graham.; RAINNIE, Al.; CHAMP, Susan McGrath. Global Descruction Networks, labour and waste. Journal of Economic Geography, n. 14,2014, p $421-441$. 
LACOSTE, Y. A pesquisa e o trabalho de campo: um problema político para os pesquisadores, estudantes e cidadãos. Boletim Paulista de Geografia. Brasil, v. 84, p. 77-92, 2006.

MASSEY, Doreen B. Pelo Espaço: Uma nova Política da Espacialidade. Rio de Janeiro: Bertrand Brasil, 2008, 312 p.

PEREIRA, Tássia Nunes Dias.; MILANEZ, Bruno.; MOREIRA FILHO, Roberto Malheiros.; NOGUEIRA, Fernando Marques de Almeida. A Reciclagem de Alumínio no Brasil e o Mercado Internacional: Uma análise quantitativa. Planejamento e Políticas Públicas, n. 10, 2016, p. 289 - 303.

RIBEIRO, Miguel Ângelo. Abordagens analíticas das redes geográficas. Boletim Goiano de Geografia, n. 1, v. 2, 2000, p. 77 - 105.

ROSADO, Rosa Maris. Na Esteira do Galpão: Catando leituras no território cotidiano da reciclagem do lixo de Porto Alegre/RS. Porto Alegre, 2009. (Doutorado em Geografia) Programa de Pós-Graduação em Geografia. UFRGS, Porto Alegre - RS, 333 p., 2009.

SANTOS, B. S. A construção multicultural da igualdade e da diferença. In: Congresso Brasileiro de Sociologia, 1995. Rio de Janeiro. Anais do Congresso Brasileiro de Sociologia. 1995.

SILVA, J. M.; MENDES, E. P. P. Abordagem qualitativa e geografia: pesquisa documental, entrevista e observação. In: MARAFON, G. J. (Org.). Pesquisa qualitativa em geografia: reflexões teórico-conceituais e aplicadas. Rio de Janeiro: EdUERJ, 2013.

SANTOS, Milton. O Espaço Dividido: os dois circuitos da economia urbana dos países subdesenvolvidos. $2^{\circ}$ ed. São Paulo: Edusp, 2008. 434 p.

SOUZA, Marcelo Lopes de. Os conceitos fundamentais da pesquisa sócio-espacial. Rio de Janeiro: Bertrand Brasil, 2013. 320 p.

Anexos

\begin{tabular}{|l|l|l|}
\hline Indústria de reciclagem de metal & Endereço & Região \\
\hline Gerdau Cosigua & Av. João XXII, 6777 & Rio de Janeiro \\
\hline & Rua Maestro Djalma do Carmo & \\
Auroge Metais Ltda & -82 & Baixada \\
\hline Balprensa Com. Ind de Ferro Ltda & Av. Coelho da Rocha, 1196 & Baixada \\
\hline Cipame & Estrada do Mendanha, 5864 & Rio de Janeiro \\
\hline & Estrada Sargento Miguel Filho, & \\
Coferro Com \& Ind de Ferro V Kenedy Ltda & 423 & Rio de Janeiro \\
\hline Correa e Alves Com de Aluminio Ltda & Rua Santos Dumont, 275 & Rio de Janeiro \\
\hline JFM Barboza & Rua Burlhões Marcial 597 & Rio de Janeiro \\
\hline Linha Amarela Reciclagem Ltda & Av Além Paraíba No $N^{\circ}$ 2008 & Rio de Janeiro \\
\hline Pacofer Paulista Comercial de Ferro Ltda & Estrada do Quitungo, 630 & Rio de Janeiro \\
\hline MW Reciclagem & Rua: Ernesto Cardoso, N $^{\mathbf{o}}$ 346a & Baixada \\
\hline
\end{tabular}

\begin{tabular}{|l|l|l|}
\hline Indústria de reciclagem de óleo & Endereço & Região \\
\hline JRM Reciclagem & Rod. Presidente Dutra Km 197 & Baixada \\
\hline Lwart Lubrificantes Ltda & Rua Edin Barbosa, s/n ${ }^{\mathbf{o}}$, Xerém & Baixada \\
\hline
\end{tabular}

\begin{tabular}{|l|l|l|}
\hline Indústria de reciclagem de vidro & Endereço & Região \\
\hline Owens Linois do Brasil & Rua Alberto Monteiro Filho, 10 & Rio de Janeiro \\
\hline Reciclaco Com. De Reciclagem de Sucata de & Estrada do Pacheco, 435 & Leste \\
\hline
\end{tabular}




\begin{tabular}{|l|l|l|}
\hline \hline Vidro & & Metropolitano \\
\hline Arruda Comercio de Vasilhames Ltda & Rua Caraíba, 51 & Rio de Janeiro \\
\hline
\end{tabular}

\begin{tabular}{|l|l|l|}
\hline Indústria de reciclagem de papel & Endereço & Região \\
\hline Cibrapel S/A Indústrias de Papel & Rua Comandante Barcelar, 731 & Baixada \\
\hline Klabin S/A & $\begin{array}{l}\text { Rod RJ 122 Rio - Friburgo, 429 } \\
\text { km 0 }\end{array}$ & Baixada \\
\hline A Arca das Caixas & $\begin{array}{l}\text { Av Pastor Martin Luther King } \\
\text { Júnior, 7015 }\end{array}$ & Rio de Janeiro \\
\hline Sociedade de Papeis Santiago Ltda & Rua Pedro Ernesto, 62 & Rio de Janeiro \\
\hline Zirbac do Brasil Com e Rec de Papéis & Rua Esmeraldino Bandeira,19 & Rio de Janeiro \\
\hline Solimar Ltda & $\begin{array}{l}\text { Rua Bispo D. João da Mata, } \\
\text { lote 25 Quadra 93 }\end{array}$ & Rio de Janeiro \\
\hline Aspergilus & Av. Nilo Peçanha, 384 & $\begin{array}{l}\text { Região dos } \\
\text { Lagos }\end{array}$ \\
\hline Paraibuna Reciclagem & Rua Henrique Burnier 700 & Minas Gerais \\
\hline
\end{tabular}

\begin{tabular}{|c|c|c|}
\hline Indústria de reciclagem de outros materiais & Endereço & Região \\
\hline Clauper & Rua Urucum, 493 & Rio de Janeiro \\
\hline Markobras & Rua Gen. Etchegoyen, 335 & Rio de Janeiro \\
\hline Nova America S/A & $\begin{array}{l}\text { Estrada Cachoeira das Dores, } \\
1693\end{array}$ & Baixada \\
\hline Primaplast Plasticos Ltda & Av Monte Castelo, 1339 & Rio de Janeiro \\
\hline Retipel & Rua Leandro Martins, 51/53 & Rio de Janeiro \\
\hline ServCooper & Avenida Alhambra & Rio de Janeiro \\
\hline Sucatão Maricá Reciclagem Ltda & $\begin{array}{l}\text { Rodovia Amaral Peixoto, km } \\
25 \text { casa } 2\end{array}$ & $\begin{array}{l}\text { Sul } \\
\text { Fluminense/Co } \\
\text { sta Verde }\end{array}$ \\
\hline Warp Services Solutions Com e Rep Ltda ME & $\begin{array}{l}\text { Rua Manoel de Souza Gomes } \\
17\end{array}$ & Rio de Janeiro \\
\hline Reciclagem Sucatas Ltda & Rua Francisco Alves, 66 & $\begin{array}{l}\text { Sul } \\
\text { Fluminense/Co } \\
\text { sta Verde }\end{array}$ \\
\hline
\end{tabular}

\begin{tabular}{|l|l|l|}
\hline Indústria de reciclagem de plástico & Endereço & Região \\
\hline Belizário Plásticos & Rua Crazeiro de Sá,44 & Rio de Janeiro \\
\hline Bell Pet Reciclagem Indústria e Comércio & $\begin{array}{l}\text { Rua Mário Alencar, s/nº - Qd } \\
53-\text { Lt 9 }\end{array}$ & $\begin{array}{l}\text { Leste } \\
\text { Metropolitano }\end{array}$ \\
\hline $\begin{array}{l}\text { Charroma Plásticos Suc. Indústria e Comércio } \\
\text { Chico Comercial e Indústria de Plásticos Ltda } \\
\text { (Salix) }\end{array}$ & Est. ambai figueira,797 galpão & Rua Gen. Taumaturgo, 338 \\
\hline $\begin{array}{l}\text { Daher e Gama Comércio de Plástico Ltda } \\
\text { (Plasbil) }\end{array}$ & Rua Nápolis, 97 & Baixada \\
\hline $\begin{array}{l}\text { Hermatek Indústria e Comércio Metalúrgico } \\
\text { Ltda }\end{array}$ & Rua Engenho do Mato, 128 & $\begin{array}{l}\text { Leste } \\
\text { Metropolitano }\end{array}$ \\
\hline IBP Indústria Brasileira de Plásticos Ltda & Rua Adelino Gonçalves, 90 & Baixada \\
\hline IMP - Indústria de Material Plásticos Ltda & Rua Teixeira Ribeiro, 308 A & Rio de Janeiro \\
\hline Indústria de Plásticos Zarzur Ltda & Rua Paula E Silva, 26 & Rio de Janeiro \\
\hline IRF - Indústria e Reciclagem Fluminense & $\begin{array}{l}\text { Av. Paulo Erlei Alves } \\
\text { Abrantes, 8560 }\end{array}$ & $\begin{array}{l}\text { Sul } \\
\text { Fluminense/Co }\end{array}$ \\
\hline
\end{tabular}


A relação entre o trabalho dos catadores de materiais recicláveis da rede de reciclagem do estado do Rio de Janeiro e a manutenção da indústria de

\begin{tabular}{|c|c|c|}
\hline & & sta Verde \\
\hline JRM 21 Indústria e Comércio de Plásticos & $\begin{array}{l}\text { Rod. Presidente Dutra Km } 197 \\
\text { - Rua E Quadra } 09 \text { lote } 45\end{array}$ & Baixada \\
\hline $\begin{array}{l}\text { L.M.G - Indústria e Comércio de Plásticos } \\
\text { Ltda }\end{array}$ & $\begin{array}{l}\text { Rua Mascarenhas de Moraes, } \\
\text { Quadra } 22 \text { - Lote } 16\end{array}$ & Baixada \\
\hline Lupe - Comércio e Indústria de Plásticos Ltda & $\begin{array}{l}\text { Rua José Tunula, s/n Quadra } 35 \\
\text { Lote } 3\end{array}$ & Rio de Janeiro \\
\hline Metalplac Indústria e Comércio Ltda & Estrada Guandu do Sapê, 34 & Rio de Janeiro \\
\hline $\begin{array}{l}\begin{array}{l}\text { NobrePlast } \\
\text { Plásticos }\end{array} \\
\text { Reciclagem }\end{array}$ & $\begin{array}{l}\text { Estrada } \\
4657, \mathrm{Km} 5\end{array}$ & $\begin{array}{l}\text { Sul } \\
\text { Fluminense/Co } \\
\text { sta Verde }\end{array}$ \\
\hline PeterLub Indústria e Comércio Plástico Ltda & RUA Josino F. Nunes, 480 & Baixada \\
\hline Plascor Line Indústria e Comércio de Plástico & Rua Maria da Glória, 133 & Rio de Janeiro \\
\hline Plastemax Indústria e Comércio & Rod. BR 040 - Km 25 & Serrana \\
\hline Plásticos Indústria e Comércio Risan Ltda & Rua Maris \& Barros 51/1202 & $\begin{array}{l}\text { Leste } \\
\text { Metropolitano }\end{array}$ \\
\hline Plastimaq Indústria e Comércio Ltda & Rua João Ramaris, 121 & Rio de Janeiro \\
\hline Plastin Indústria e Comércio de Plástico & Rua Cuba, 201 & Rio de Janeiro \\
\hline PlastQuimica Indústria e Comércio Ltda & Av. Monte Castelo, 1616 & Baixada \\
\hline $\begin{array}{l}\text { Pluriplast Indústria e Comércio de Plásticos } \\
\text { Ltda }\end{array}$ & $\begin{array}{l}\text { Av. Antônio Mário de Azevedo } \\
4198\end{array}$ & Serrana \\
\hline Poli Injet Indústria e Comércio de Material & Av. Nilo Peçanha, 1160 & Baixada \\
\hline $\begin{array}{l}\text { Politubos Indústria e Comércio de Plásticos } \\
\text { Ltda }\end{array}$ & $\begin{array}{l}\text { Estr. Conselheiro Paulino, } \mathrm{s} / \mathrm{n}^{\circ} \\
\mathrm{Km} 0\end{array}$ & Serrana \\
\hline 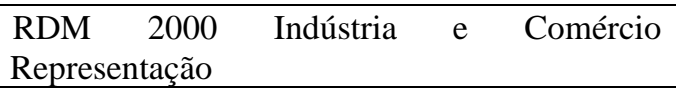 & Rua Palermo, 128 & Baixada \\
\hline $\begin{array}{l}\text { Reale Plásticos Indústria } \\
\text { Reciclável }\end{array}$ & Av. Prudente de Morais, 990 & Baixada \\
\hline $\begin{array}{l}\text { Faizão Indústria e Comércio de Reciclados } \\
\text { Ltda }\end{array}$ & Rua Quipapa,102 & Baixada \\
\hline Faria Plásticos Comércio de Recicláveis Ltda & Rua Monte Castelo, ${ }^{\circ} 1.700$ & Baixada \\
\hline $\begin{array}{l}\text { Pacofer Paulista Indústria e Comércio de } \\
\text { Ferro e Máquinas Ltda }\end{array}$ & $\begin{array}{l}\text { rua balduino de aguiar n } 295- \\
\text { galpão }\end{array}$ & Rio de Janeiro \\
\hline $\begin{array}{l}\text { RecPlast Indústria e Comércio Material } \\
\text { Plástico }\end{array}$ & $\begin{array}{l}\text { RUA Mascarenhas de Moraes, } \\
1035\end{array}$ & Baixada \\
\hline Roma Plásticos Indústria e Comércio Ltda & Rua Pinto Djalma Costa, 137 & Rio de Janeiro \\
\hline Guanapel Embalagens Ltda & $\begin{array}{ccc}\text { Rua } & \text { Bernardo } & \text { Figueiredo, } \\
56 / 86 & & \end{array}$ & Rio de Janeiro \\
\hline
\end{tabular}


A relação entre o trabalho dos catadores de materiais recicláveis da rede de reciclagem do estado do Rio de Janeiro e a manutenção da indústria de reciclagem Uilmer Rodrigues Xavier da Cruz

\begin{tabular}{|l|l|l|}
\hline Frilca Indústria e Comércio de Sacos Plásticos & Rua Adelaide Badajós, 38 & Rio de Janeiro \\
\hline Bauen Indústrias de Plásticos Ltda & Rua da Regeneração, 489 & Rio de Janeiro \\
\hline Prensa Brasil Ltda & $\begin{array}{l}\text { Avenida Retiro da Imprensa, } \\
\mathrm{n}^{\circ} 1793\end{array}$ & Baixada \\
\hline Dutoplast Indústria e Comércio Ltda & Rua Jesus Soares Pereira, 466 & $\begin{array}{l}\text { Norte } \\
\text { Fluminense }\end{array}$ \\
\hline Âncora Indústria e Comércio de Estopas & Rua Santos Dumont, 45 & Baixada \\
\hline Polyrio & $\begin{array}{l}\text { Av. Presidente Tancredo } \\
\text { Neves, 3503 }\end{array}$ & Baixada \\
\hline Granplast Indústria e Comércio de Plásticos & Rua Ubaldina, 1170 & Baixada \\
\hline
\end{tabular}

\begin{tabular}{|l|l|l|}
\hline Indústria de reciclagem de pneu & Endereço & Região \\
\hline Borracha Reciclada & Estrada união e indústria, 620 & Três Rios \\
\hline
\end{tabular}

